DOI: 10.20472/EFC.2019.012.021

\author{
EKATERINA SEMERIKOVA \\ Moscow School of Management SKOLKOVO, Russian Federation \\ EGOR KRIVOSHEYA \\ Moscow School of Management SKOLKOVO, Russian Federation \\ ALEXANDER DOBRYNIN \\ National Research University - Higher School of Economics, Russian Federation

\section{PERCEPTION OF ACCEPTANCE BARRIERS AND CASHLESS PAYMENTS VALUE: EVIDENCE FROM RUSSIAN MERCHANTS}

\begin{abstract}
:
This study is aimed to examine the effect caused by perception of higher card acceptance barriers on cashless revenue share of Russian merchants. The empirical testing is conducted based on two representative samples of Russian nation-wide merchants survey data collected in 2014 and 2017. The analysis considers a set of regional controls, as well as merchant-specific characteristics. The statistically significant evidence in favor of negative impact caused by perception of higher infrastructural barriers on cashless revenue share is found in both samples, while only a partial significance of higher perceived institutional and human capital barriers may be observed. No significant evidence for merchants' rationality with respect to acceptance barrier has been found based on the comparison of perceived and actual barriers effects.
\end{abstract}

\title{
Keywords:
}

retail payments; financial services; merchants; barriers; card acceptance

JEL Classification: G21, D53, E42 


\section{Introduction}

Cashless payments have recently been expanding throughout the world with a considerable pace. According to the World Payments Report (2018), the global yearly number of non-cash transactions has almost reached 500 billion in 2016, with the figure growing at more than $10 \%$ annually. Although most of these transactions are executed in the US and Eurozone, Russia and a series of other emerging economies appear as the core drivers of digital payments growth.

Russia has indeed been experiencing a significant improvement of the non-cash payments usage. The volume of operations with payment cards has increased by 14\% in 2018 based on the statistics provided by Bank of Russia. The growth is almost fully driven by the rise in actual cashless payments using cards (34\%), while the volume of operations on cash withdrawals has only improved by $3 \%$. At the same time, the number of cash withdrawals keeps falling for the second year in a row, having reached the peak in 2016 (3,4 billion operations). By the end of 2018 the volume of operations involving transactions with the use of cards has risen by 6,2 percentage points, reaching over $41 \%$ share of total payment card usage volumes.

Having set a new agenda for the world economy in general, digital payments are in the spotlight of academic research. So far the existing literature on the topic has been mostly involved in the investigation of card acceptance and usage incentives and barriers, specifically with respect to retail payment market (Arango, P. Huynh, \& Sabetti, 2015; Arango-Arango, Bouhdaoui, Bounie, Eschelbach, \& Hernandez, 2018; Bolt \& Chakravorti, 2008; Borestam \& Schmiedel, 2011; Krivosheya \& Korolev, 2016, 2018; Loke, 2007; Rochet \& Tirole, 2002, 2003, 2011; Rysman, 2007; Weiner \& Wright, 2005). Besides the general evaluation of determinants, an increasing stand of literature examines the network effect, developing the idea of Rochet and Tirole (Bounie, François, \& Van, 2016; Carbó-Valverde, Liñares-Zegarra, \& Rodríguez-Fernández, 2012; Krivosheya, 2018; Krivosheya \& Semerikova, 2018). However, only a limited number of papers have analyzed the perception effects regarding various components of cashless payments integration within the retail market, aside from the actual effects of barriers (Arango \& Taylor, 2008a; Kim, Tao, Shin, \& Kim, 2010; Mimouni-Chaabane \& Volle, 2010).

As of 2016, around 30 percent of retail payments in Russia were conducted on a non-cash basis, while more than 50 percent of Russian citizens regularly use cashless methods of payment (Krivosheya et al., 2017). The popularity of digital payments has come with a set of benefits offered to the end-users, most of which are either merchants or consumers (Krivosheya \& Korolev, 2016, 2018; Krivosheya, 2018). However, the expansion of cashless payments is heavily dependent on the environment and its participants. It is crucial that all parties are ready and willing to pay with the cashless means, in case of consumers, or accept them, in case on merchants. In this paper the latter participants of non-cash payment market will be analyzed more precisely. A closer investigation of merchants' behavior with respect to cashless payments allows us to indicate significant factors effecting non-cash revenue, which may be found useful by both the regulator and retailers themselves. In particular, an examination of acceptance barriers and their perceptions could enable authorities to promote cashless economy more effectively and merchants to alternate their attitude with a benefit to a firm.

Despite all the benefits faced by the retailers with in introduction of cashless payments (Krivosheya \& Korolev, 2018; Krivosheya, 2018; Mimouni-Chaabane \& Volle, 2010), merchants still report issues preventing them from installing and maintaining the cashless system within their stores. Merchants can face difficulties on all the stages of digital payments integration, from underqualification of workers and equipment malfunctioning to insufficient quality of interaction 
with banks or acquirers. Although the barriers thought to have both direct and indirect influence on merchants' cashless revenues, barriers perception by the retailers is another profound and yet poorly investigated field to explore. Retailers' attitude towards the possible obstacles arising from cashless payments integration may affect the share of cashless revenues in a way not less of an interest than the barriers themselves.

Analysis of the existing literature allows us to form three major blocks of acceptance barriers based on their nature and potential effect on merchants' cashless revenue. Human capital barriers mainly arise due to underqualification of the workers with respect to operating and maintaining POS-terminals, leading to potential costs from search and training of the employees. Infrastructural barriers are associated with the quality of the Internet connection, as the acquiring terminals are generally sustained with a stationary or mobile network, and the equipment breakdowns with all the expenses on repairments and extended queueing time. Finally, the institutional barriers reflect potential issues arising from merchants' cooperation with banks and acquirers, which may fail to provide the adequate support regarding the cashless payment system installment and maintenance. Moreover, the speed of remittances may also be included into the third block due to potential languor in operations.

The key research question of the paper is whether the perception of acceptance barriers has any correlation with the share of cashless revenue. Moreover, the presence of the barriers and significance of their direct effect on non-cash revenue share can be examined as well. This will potentially allow us not only to see the effect perception and expectations regarding the barriers have on actual revenue figures, but also to see if merchants' expectations coincide with the real effect barriers have on the cashless revenues. As a result, the rationality of merchants' perception and expectations regarding the acceptance barriers' effect on cashless revenue share may be assessed.

Based on two representative samples containing the nation-wide survey information among 800 Russian merchants for 2014 and 2017, the empirical analysis has found evidence for the negative effect of several acceptance barriers' perceptions on the cashless revenue share. Moreover, the regional expenditures on network services has proven to positively affect the noncash share of merchants' revenues, with no significance found for the human capital proxy. The rationality of merchants could only be substantiated with respect to some barriers or blocks, with no possibility of evident general conclusion.

This study contributes to the rising strand of academic literature on the topic of cashless payments (Arango et al., 2015; Arango \& Taylor, 2008b; Bounie et al., 2016; Krivosheya \& Korolev, 2016, 2018; Loke, 2007; Rochet \& Tirole, 2002, 2003; Rysman, 2007; Weiner \& Wright, 2005), and on the issue of merchants' perception effects particularly ((Arango \& Taylor, 2008a; Krivosheya, 2018; Mimouni-Chaabane \& Volle, 2010), in several important considerations. Firstly, the study analyzes the acceptance barriers and their perceptions by the merchants in relation to the share of cashless revenue, which allows for estimation and comparison of the effects observed. Secondly, when testing the potential existence of barriers in general, several regional characteristics not considered in the previous works on the topic will be accounted for. Finally, merchants' rationality with respect to the acceptance barriers will be discussed based on the estimation results.

The practical implications of the study are incorporated in the extended stance of insights regarding merchants' perceptions and the actual effect of acceptance barrier on the share of cashless revenue. This information can be found application by the regulators, desiring to construct a proper set of policies for digital payments market and aiming to achieve equilibrium 
outcome to maximize the combination of consumer and producer surpluses. Moreover, the merchants' further perception, and, consequently, conduct can be modified based on the significance of actual barriers effect on the cashless share of revenues.

The paper consists of five key sections including the introductory part. In the following section the theoretical foundation for the research question will be presented based on the related literature review and the description of barriers' perception mechanisms. The set of hypotheses to be examined further will be formulated in the next section as well. Section 3 will introduce the empirical framework of the study, including data sources, models, variables and estimation methodology. Section 4 will analyze the significance and give the interpretation of obtained results. Finally, section 5 will outline the general findings of the paper and set agenda for further research on the topic.

\section{Theoretical framework and literature review}

\subsection{Rational expectations and perception of acceptance barriers}

Before exploring card acceptance barriers, their perception by merchants and eventual effect on cashless revenue, it may be practically useful to analyze the rationality of expectations and its role in decision making process. The concept of rational expectations, originally introduced by John F. Muth (1961) and developed further by Robert Lucas $(1972,1976)$ in a macroeconomic field, is widely used as a key assumption in economic papers. Generally, expectations are considered rational if they are the best guesses of future outcomes, which in a long-run allow the market to equilibrate (Muth, 1961). A number of the broad studies testing expectations reveal mixed evidence regarding the possibility of expectations to be rational in the first place (Bao, Hommes, Sonnemans, \& Tuinstra, 2012; Hommes, 2013). Nevertheless, the concept can be applied in both theorical and practical fields. On the one hand, assumption of rational expectations is fundamental to build a benchmark for market outcomes of various models proposed in economic research. On the other hand, it enables the policymakers to consciously and efficiently regulate the market in case of possible deviations to reach the equilibrium or at least seize the volatility around it. Therefore, assessing the rationality of market participants may be seen as one of the necessary steps prior to any actions affecting the market efficiency.

If one goes beyond the formal definition of rationality, expectations act as a cornerstone for any actual decision-making process, and the retail business is not an exception. Expectations initially form a basis for our perception of the upcoming events and other market features arising with time (Hermann, Pentek, \& Otto, 2016). Despite being more of a psychological issue, expectations are, nonetheless, indirectly affect our attitude towards the subject through perception alternations (Bahamonde-Birke, Kunert, Link, \& Ortúzar, 2017). Eventually, having perceived the subject and having formed an attitude towards it, we build the behavioral pattern, the way we act and make certain decisions (Zwart-van Rijkom, Leufkens, Busschbach, Broekmans, \& Rutten, 2000). Building upon this idea further, given an individual has rational expectations, s/he will eventually act in accordance with the efficient market outcome in long-run. Hence, perception of the subject may be considered both a catalyzer of certain conduct and a proxy to elaborate around the expectations.

Although the cashless means of payment have been gaining the popularity in recent decades, the process of complete digitalization in this field remains relatively distant for several reasons. Firstly, not all the consumers, particularly in Russia, are either fully aware about the spectrum of cashless economy possibilities or accustomed to the regular use of cards. According to NAFI Research Centre, in 2017 only around 30\% of Russian citizens prefer cashless payments to 
cash, while $18 \%$ of citizens have no intent to apply for a card in the nearest future. Secondly, not all the merchants are capable and willing to install and maintain the technology at their stores. A retailer, as any market participant, faces a cost-benefit trade-off regarding the decision of cashless payment system implementation. While the benefits of retail payments card market have been investigated vastly (Krivosheya \& Korolev, 2016, 2018; Krivosheya, 2018; MimouniChaabane \& Volle, 2010), the costs, and especially barriers preventing merchants from card acceptance, have not yet been significantly evaluated in academic literature. Finally, authorities play another key role in spreading the usage and acceptance of card on the market by formulating and executing a specific set of regulatory norms regarding the field. Therefore, it seems relevant to explore the barriers of card acceptance and their effect on merchants' cashless revenue to pinpoint the most significant preventing factors to be addressed by both merchants and authorities.

Card acceptance barriers, seemingly alike in their effect on merchants' cashless revenues, still differ in their nature and agents involved. Besides, the mechanisms of influence also vary in their time horizons. Let us first focus on forms barriers may take and evidences of problems regarding the adoption of electronic payments.

The key general arguments for digital payment system implementation within the economy are reduction of cash processing time and robbery rates, promotion of economic development, improvement in treasury management, among others (Nwankwo \& Eze, 2013). However, a set of certain reforms is required from the authorities in order to migrate towards cashless society. Not only the public is deeply rooted into using cash, but also the infrastructural and institutional facilities remain far behind in some developing countries. This refers to the speed and quality of connection, amount of equipment breakages and power failures, as well as to the quality of banks and regulatory authorities' services. These issues are not only stalling the move towards digitalization of the economy government-side - they are also preventing merchants from cashless payments acceptance.

Moreover, there is evidence of other factors affecting the decision of non-cash transaction enablement within the retailers. In a set of emerging economies (India, Nigeria, etc.) human capital is a cornerstone for the all-round national development (Hanushek, 2013). Apart from physical and infrastructural drawbacks, these countries face a considerable lack of capable and well-educated workers, ready to operate and maintain the terminals for cashless transactions properly. Even though some part of the poorly educated society is willing to work, the retailer can bear considerable search costs due to high risk of operational malfunctions caused by unskilled workers (Rahim, Atan, \& Kamaluddin, 2017). Thus, all the barriers can be conventionally organized into three major blocks: infrastructural barriers, human capital barriers and institutional barriers, with the latter being related to the bank-merchant relationship.

However, not only barriers themselves are the obstacles of acceptance. Having formed their expectations, merchants face a broad spectrum of barriers and eventually act according to their perception. While the actual barriers prevent retailers from cashless system adoption by restricting the operations and incurring extra costs, even if the merchant is willing to digitize the transactions within the store, perception of these barriers can put additional restraints. The merchant may simply try to avoid the installment or maintenance by intentionally shutting down POS-terminals, postponing the acquiring contract initiation with the bank or perform any other deceptive conduct due to the expected threat to the business. Even though the financial institutions may render high-quality services and the connection quality within the region may be stable and prompt, the retailer still has a possibility to object card acceptance due to incorrect 
perception of barriers. On the other hand, if merchants' expectations about the effect acceptance barriers have on cashless revenues and their share in total revenues are consistent with their actual influence, the retailers' actions and perception may be considered rational. Regardless of the outcome, the information about merchants' rationality and perception of barriers may be used to conduct the optimal regulatory policy for reaching the market equilibrium and shifting the society towards the cashless economy in general. Let us now assess the effects barriers and their perception have on merchants' share of cashless revenues by examining the mechanism of each abovementioned block and its components.

\subsection{Infrastructural barriers}

Infrastructural barriers are mostly related to the connection quality and stability. Being majorly dependent on the Internet connection, POS-terminals serve a key role in maintaining the cashless transactions possibility using non-cash means. Apart from the direct transaction validation using the terminals, the revenues cannot immediately be perceived, since transferring cashless funds into the merchants' bank account may also take a considerable amount of time. Therefore, connection quality may per se affect the cashless revenues through two main channels. Firstly, the stability of Internet access and minimized amount of line breakages may result in lower maintenance costs, since no extra payments will be required for timely repairs or even a provider change (Voges \& Pulakanam, 2010). Moreover, queuing time caused by connection malfunctioning may be minimized, leading to extra cost cutting. Besides apparent turnover acceleration, improved customers' perception of service quality may potentially have positive reputation effects (Grunig \& Hung, 2002). As a result, both the number of customers and each customers' amount of transactions are expected to rise, as well as transaction volumes. Secondly, the speed of requests processing enables transactions to be completed quicker, which depletes queueing time and, eventually, improves customers' satisfaction and turnover again.

However, merchants' perception of infrastructural barriers can also affect cashless revenues apart from barriers themselves. Having formed expectations regarding the possible issues with adoption of card payments, retailer may object to promote the cashless means of payment within the store by intentionally "breaking" the POS-terminals or postponing the payments for communication bills, thus preventing the connection stability and under-receive non-cash revenues. This allows us to state the following hypothesis:

\section{H1: Perception of higher infrastructural barriers negatively affects the share of cashless revenue}

\subsection{Human capital barriers}

Besides infrastructural issues affecting the cashless revenues of merchants, human capital barriers also play a considerable part in installation and maintenance of digital payment systems decisions. Inability or lack of competence regarding the terminals may negatively affect the potential cashless revenues of merchants through several channels. Poor education quality within a certain region is the first possible barrier for store operation and, consequently, for revenue generation. Insufficiently low amount of well-qualified workers available on a labour market may result in greater search costs and operation deference, as well as in insecurity of cashless payment system installment and maintenance (Mandal, 2017; Rahim et al., 2017). Moreover, the inability of already employed workers to use and operate these systems efficiently and promptly may serve as a reason for excessive waiting time and low customer satisfaction in general (Aboyasin \& A. F. Sultan, 2017; Chowdhury, Schulz, Milner, \& Van De Voort, 2014; Luthans \& Youssef, 2004). 
From the expectational perspective, merchants may not want to risk their operational efficiency by delegating the digital payments processing tasks to unskilled workers. Even if the owner is not extremely averse to risk, perceived costs associated with search and training the personnel induce him/her to avoid or postpone cashless payments system installment. Therefore, cashless revenue and its share may be eventually adversely affected, and the follow hypothesis may be stated:

H2: Perception of higher human capital barriers negatively affects the share of cashless revenue

\subsection{Institutional barriers}

Finally, institutional issues form a third major group of barriers for cashless economy expansion within the retail enterprises. Merchants are dependent heavily on the nature and structure of relationship with their bank-acquirer, as well as on the conditions under which the contract between these two parties is signed. Bank may affect the merchants' cashless revenues both directly and indirectly. On the one hand, the terms specified in the contract may indicate a share of cashless revenues charged as a fee merchants have to pay to the bank (Rochet \& Tirole, 2003). On the other hand, the quality and ease of formal contract execution with the subsequent support from the bank may affect merchants' decision about the cashless payment acceptance and non-cash revenues themselves by boosting or stalling the operating processes of the enterprise (Arango \& Taylor, 2008b). Moreover, improper support of acquiring services may negatively affect the speed of cashless revenue generation in case of delays with installment and further maintenance of the equipment (Juras \& Jones, 2011; Kellogg, 2008). Finally, delay in remittances of cashless revenues to the merchant's bank account may also impact the speed of operations, which may potentially affect the turnover (Arango \& Taylor, 2008a). The funds received to the account are generally either deposited or brought back into the business for operating expenses. Besides, the disbursement of loan, in case it has been taken by the merchant, may be postponed due to transfer lags, leading to possible issues with credit records.

Issues arising from bank-merchant relationship may put additional pressure on merchants' perception of institutional barriers. As a result, merchants may incur extra costs searching for an optimal acquiring services provider or choosing not a provider with poor reputation yet moderate fees, which can again have a detrimental effect on cashless revenues share and digital payments acceptance in general.

\section{H3: Perception of higher institutional barriers negatively affects the share of cashless revenue}

Additionally, perception of infrastructural and institutional blocks' components could be tested as well to enhance the analysis. Thus, 5 more hypotheses are stated as follows:

H4: Perception of higher connection quality barriers negatively affects the share of cashless revenue

H5: Perception of higher terminal malfunctioning barriers negatively affects the share of cashless revenue

H6: Perception of higher banking support barriers negatively affects the share of cashless revenue

H7: Perception of higher acquiring support barriers negatively affects the share of cashless revenue

H8: Perception of higher remittances speed barriers negatively affects the share of cashless revenue 
All the barriers discussed above were to different extents perceived by the merchants as cramping the process of card acceptance. Testing the abovementioned hypotheses would allow us to conclude on the barriers' perception significance for merchants' cashless revenue share. However, the joint significance should be additionally tested to check for the combined effect perception of barriers in general may result in. Perception of each individual block by itself may be found not significant, while the joint effect may turn out to be different and vice versa. Hence, the additional hypothesis can be formulated as follows:

\section{H9: Perception of higher acceptance barriers negatively affects the share of cashless revenue.}

Finally, the discussion of differences in actual barriers and their perception relative to non-cash revenues should be brought forward. As previously mentioned, acceptance barriers may have not only the direct effect on the cashless payments' adoption decision of merchants - perceived costs and disruptive issues associated with card acceptance should be taken to account as well. Although we can blindly assume the rationality of merchants when making their decisions, empirical evidence suggests that actions based on expectations may deviate from rational due to informational imperfections of the market, which eventually affects the efficiency of market outcome (Kahneman, 1994; Lovell, 1986; Simon, 1990). The rationality of merchants regarding their perception of acceptance barriers may be tested by comparing the actual impact barriers have on retailers' cashless revenue share and the perception of these barriers. The outcome of this test would not only contribute to the existing literature on rationality of market participants' expectations but would also allow authorities to adjust the set of policies regulating bankmerchant relationship and make necessary improvements in terms of infrastructure and human capital accumulation and preservation. Therefore, the following hypothesis may be formulated:

\section{H10: Merchants have rational expectations regarding acceptance barriers' effect on the share of cashless revenue}

In the following section the empirical set-up of the study will be presented, with a broad discussion of the used data, models, variables and estimation methods.

\section{Empirical set-up}

\subsection{Data}

All the hypotheses will be tested using several data sources. The core source for investigating the effect of merchants' perception of cashless economy barriers will be the nation-wide proprietary survey of Russian merchants, conducted by Moscow School of Management SKOLKOVO in two waves: 2014 and 2017. The survey covered retailers from all federal regions and of various shop types/sizes and uses quotas for both features to ensure samples' representativeness. The study consists of an extensive questionnaire, mainly focusing on card acceptance, merchants' attitude towards possible barriers, acquirer-merchant relationships, fees and retailers' intentions regarding the switch to the non-cash payments. The samples were formed based a series of face-to-face interviews and include both card-accepting and currently non-accepting merchants. Due to the time gap in the survey waves, the study will be performed by analyzing two crosssectional datasets separately.

The first sample (2014) includes 806 observation, with stalls and kiosks covering $35,1 \%$ of merchants, representing the largest group of retailers. More than a half of merchants report to specialize in selling food and beverages (54,77\%). Stores are more evenly distributed among the federal regions, with the Central Federal Region slightly overweighing the rest (18,34\%), and 
most cities considered have a population of over one million people $(37,55 \%)$. Only $50,56 \%$ of respondents accept cashless payments in their stores, so the two-step Heckman selection model will be applied further to estimate the probability of acceptance of the remaining part of merchants. The first wave does not cover online retailers.

The second wave of study (2017) additionally covered online retailers, which had to be excluded for the current research due to inability to attribute any regional characteristics to this type of merchants. As a result, the final sample contains 668 observations, among which $62,6 \%$ accept cashless payments. Kiosks and stalls again appear as the largest retailer type, however, with a smaller share than in the first wave $(27,6 \%)$, with mostly selling food and beverages. $18,83 \%$ of respondents are located in the Central Federal Region, which also takes the largest portion of the sample. Overall, the results obtained based on the following samples may be compared due to similar underlying approaches to sample formation.

Moreover, to test the actual effect of barriers on the share of cashless revenue different proxies for the level of human capital and connection quality are obtained. The ratio of number of bachelors, specialists and masters graduated during the year to the regional population is used as a proxy for the level of human capital. The statistics was retrieved from Rosstat for 2013 and 2016 years in an attempt to control for possible endogeneity with the use of corresponding instruments.

As for connection quality, and infrastructural conditions in general, there are at least two proxies based on Yandex Research and Rosstat publicly available online. The first proxy is the average speed of stationary broadband access in 2013 and 2016 by Federal regions of Russia, with Moscow and St. Petersburg considered separately. The choice of stationary broadband access instead of mobile is substantiated by the fact that the major part of acquiring terminals are based on stationary connection, according to Yandex report on the Russian Internet environment in 2016. The role of the second proxy for connection quality, and infrastructural barriers in general, plays the volume of regional network services per capita, also collected from Rosstat for 2013 and 2016.

Bank-merchant or acquirer-merchant relationships, as well as transaction delays, are considerably particular barriers to use proxies for and no relevant data regarding the infrastructural barriers were found, thus, leaving this issue for the further research on the topic. As one of the viable choices, the regional level of banking system trust and average transaction processing speed by banks/acquirers could be suggested.

\subsection{Models}

The study refers to the two-step Heckman selection model to test the hypotheses on the effect perception of acceptance barriers has on the share of merchants' cashless revenue. As the samples contain data on both types of merchants (accepting and non-accepting cards as a payments method in their stores), on the first step we may estimate the probability of second type's acceptance. This enables us to minimize the potential selection bias on the second step, where we run the share of cashless revenue on a certain set of explanatory variables. The generalized models are based on Krivosheya (2018) study of end-users benefits on the retail payment market, with the extension accounting for the perceptual and actual effects of acceptance barriers. 
Generalized model for merchants' perceptions effect on cashless revenues looks as follows:

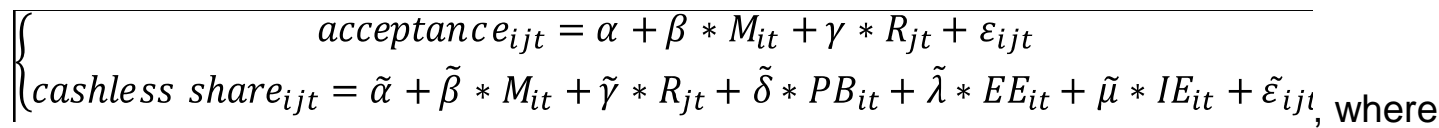

acceptance $_{i j t}$ indicates the dummy variable, which takes the value of 1 in case the merchant $i$ operating in region $\mathrm{j}$ and participating in the survey at the time $t$ accepts cashless payments and zero otherwise. $\sqrt{M_{i t}}$ represents the vector of merchant-specific variables, while $\sqrt{R_{j t}}$ is the vector of regional characteristics. $\sqrt{\varepsilon_{i j t}}$ is the vector of error terms, while other notations in the first equation

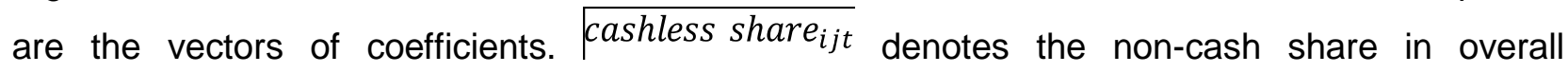

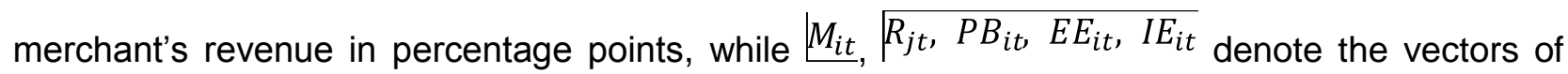
merchant-specific variables, regional characteristics, perception of acceptance barriers, external environment variables and internal environment variables. $\tilde{\varepsilon_{i j}}$ is the vector of error terms, while other notations correspond to the vectors of coefficients. In is worth mentioning that perceptions of acceptance barriers will be examined both separately and in blocks.

Depending on the output, we can also estimate the effect actual barriers have on the share of cashless revenue. The model will, as well as the former one, account for the possibility of accepting cashless payments for those merchants, which currently are not. The crucial difference will be reflected on the key vector of explanatory variables in the second equation, as in this case the actual effect of acceptance barriers on the share of cashless revenue will be examined instead of the perception effect.

The actual barriers' effects on cashless revenues will then be modelled as follows:

$\left\{\begin{array}{c}\text { acceptanc } e_{i j t}=\alpha+\beta * M_{i t}+\gamma * R_{j t}+\varepsilon_{i j t} \\ \text { cashless share }_{i j t}=\tilde{\alpha}+\tilde{\beta} * M_{i t}+\tilde{\gamma} * R_{j t}+\tilde{\delta} * B_{i t}+\tilde{\lambda} * E E_{i t}+\tilde{\mu} * I E_{i t}+\tilde{\varepsilon}_{i j 1} \text {, where }\end{array}\right.$

$\sqrt{\text { acceptance }_{i j t}}$ indicates the dummy variable, which takes the value of 1 in case the merchant $i$ operating in region $\mathrm{j}$ and participating in the survey at the time $t$ accepts cashless payments and zero otherwise. $M_{i t}$ represents the vector of merchant-specific variables, while $\sqrt{R_{j t}}$ is the vector of regional characteristics. $\overline{\varepsilon_{i j t}}$ is the vector of error terms, while other notations in the first equation are the vectors of coefficients. $\overline{\text { cashless } \text { share }_{i j t}}$ denotes the non-cash share in overall merchant's revenue in percentage points, while $\underline{M_{i t}}, \overline{R_{j t}, B_{i t}, E E_{i t}, I E_{i t}}$ denote the vectors of merchant-specific variables, regional characteristics, proxies of acceptance barriers, external environment variables and internal environment variables. $\overline{\varepsilon_{i j t}}$ is the vector of error terms, while other notations correspond to the vectors of coefficients.

Finally, the rationality of merchants will be assessed by comparing the corresponding coefficients obtained from two models above based on signs and significance. Formal testing would be of the utmost interest; however, the construction of this test requires further analysis and additional research, which is out of scope of the current paper.

\subsection{Dependent variables}

On the second step of estimation in both models considered above, cashless share of merchant's revenue is self-reported by the respondents and may take a value between 0 and 100 (in 
percentage points). Acceptance is modelled as a dummy and serves as a dependent variable on the first step of estimation (selection equation) and is also self-reported by merchants.

\subsection{Explanatory variables}

Perception of acceptance barriers is considered the main explanatory variable of our interest and is represented as a set of dummy variables, which take a value of 1 in case the merchant reports any of the possible issues with cashless payments acceptance as either moderate or major problem and zero otherwise. The list of issues offered to the respondents includes insufficient workers' skills, poor connection quality, machinery breakdowns, insufficient bank and acquirer support and money transfer delays. The perception of acceptance barriers will be tested using all the barriers separately, as well as by grouping them into three respective blocks. The dummy variable for perception of blocks will be assigned 1 if at least one of the barriers in a block is reported as a moderate or major issue, zero otherwise.

The set of explanatory variables for examining the actual barriers' effect includes two proxies for barriers, constructed using government public statistics. To estimate human capital effect on merchant's cashless revenue share there is be formed a proxy based on the yearly regional population figures and regional number of university graduates within a certain year (bachelors, specialists and masters). As a result, the number of graduates per capita (in percentage points) is found for each federal subject of Russia, enabling us to estimate the effect of human capital on cashless revenue share. Moreover, the infrastructural barriers' effect is evaluated based on the regional volume of network services per capita (in thousand rubles). This figure considers the monetary amount of services provided by the legal entities and individual entrepreneurs (residents) to Russian citizens and non-residents. The data is gathered by Rosstat on a yearly basis. The average Internet connection speed (both stationary and mobile) data is only available on the level of federal regions, which questions the relevance of this variable as a proxy for infrastructural effect.

\subsection{Control variables}

Merchant-specific characteristics include merchant's type (supermarket, food and non-food stores, stalls, pharmacies or minimarkets) and commodity lines (food and beverage, durables or clothes and shoes), of which merchants self-reported in the questionnaire. Moreover, the dummies for company size are included depending on the yearly revenue volumes $(0 \mathrm{~m}-1 \mathrm{~m}$ RUB, $1 m$ - 10m RUB, 10m - 100m RUB, >100m RUB).

Regional characteristics include the specification of the Federal District the merchant is located into (Central, Northwestern, Volga, Siberian, Southern, Far Eastern, Ural or North Caucasian) and city size ( $<100 \mathrm{k}$ citizens, $100 \mathrm{k}-500 \mathrm{k}$ citizens, $500 \mathrm{k}-1 \mathrm{~m}$ citizens, $>1 \mathrm{~m}$ citizens). Moreover, GRP per capita and retail regional trade volume per capita were included in several specifications. The latter two were collected as of 2013 and 2016 correspondingly in order to control for possible endogeneity via the inclusion of past observations in the samples. Regional characteristics are collected based on the public government sources (Rosstat).

Internal merchant environment includes such particular store characteristics as the number of merchants' market presence years (experience) and a dummy for being a part of retail chain network to control for possible variations compared to individual enterprises. Besides, the value of an acquiring fee and partaking in a loyalty program is reported by the retailers as well to consider the acquiring- and bank-related details. External merchant environment is mainly represented by the competitiveness of the local market regarding card acceptance and accounted for via inclusion of a dummy, which takes a value of 1 in case more than $50 \%$ of 
competitors accept payment cards and zero otherwise, as perceived by the merchant. Finally, a dummy for the city of store location being a regional center is included as well.

Some specifications of both models include regional features (logarithms of GRP per capita and retail trade volume per capita, both retrieved from Rosstat) apart from all the variables discussed above. Together with regional dummies, this will allow to account for endogeneity caused by omitted controls.

\subsection{Estimation methods}

Considering the previous works related to the topic of Russian merchants' behavior and perception regarding the cashless payments (Krivosheya \& Korolev, 2018; Krivosheya, 2018), this study will also apply two-step Heckman selection model to account for a two-step structure of barriers' effect estimation process. In order to mitigate any possible selection bias associated with inclusion of non-card-accepting retailers in our analysis, the probability of potential acceptance of cashless payments by this type of merchants should be estimated on the first step, which is modelled as probit regression (Heckman, 1976). Following this procedure, the effect of barriers' perception or the actual barriers effect on the share of cashless revenues can be examined. It is worth mentioning that the similar approach was applied by Krivosheya \& Korolev (2016) to evaluate the benefits of cardholders on the Russian retail market as well.

The choice of two-step Heckman model is also supported by Krivosheya \& Korolev (2016) article by the fact that the authors managed to demonstrate that Heckman regression outperformed the alternative approach of running two independent regressions. Finally, the inclusion of regional dummies allows to control for possible regional fixed effects in years the survey was conducted (Krivosheya \& Korolev, 2018; Krivosheya, 2018) Generally, Heckman correction for sample selection is vastly used to minimize the selection bias when dealing with non-randomly generated samples (e.g. consisting of observations). The applications of this model may be found in a broad series of works on social sciences (Certo, Busenbark, Woo, \& Semadeni, 2016; Clark \& Houle, 2014; Xu et al., 2017).

Nevertheless, Heckman two-step correction model meets a series of critique in academic literature as well. Apart from the inefficiency claims (Nawata, 1994), Goldberger (1983) noted the weakness of the error terms joint normality assumption, failure of which could potentially lead to the inconsistency of the obtained estimator. Although the remark is generally correct, the assumption may be maintained due to the size of the samples used in the study. Besides, Puhani (2000) commented on the necessity of inclusion of at least one explanatory variable with a nonzero coefficient in the selection equation, which will not be, at the same time, present in the second regression. This study addresses this note by accounting for regional characteristics (GDP per capita and retail regional trade volume per capita). The same work also mentions the inconsistency of the resulting covariance matrix obtained on the second stage of estimation, which is suggested to be resolved with the use of bootstrap to improve the quality of test statistics. This issue is relevant and could be taken into account by the application of resampling methods in further papers on the topic.

Tables 1-1 and 1-2 present the descriptive statistics for 2014 and 2017 samples. Panels 1 and 2 present the cross-correlation matrixes for all the variables included in the study for 2014 and 2017 samples correspondingly. As can be concluded from the table, no extreme multicollinearity among the key variables is observed. Variables with high correlation are either not jointly considered into one model or play a role of controls and have been proven to not affect the 
estimation outcome in case they are included (see appendix).

Table 1 goes here.

\section{$4 \quad$ Results}

This section will focus on evaluation and interpretation of the results obtained by running a series of regressions based on two samples (2014 and 2017). There will be several specifications within each wave: first, we will consider perception of each block of barriers; secondly, the six individual acceptance barriers' effect will be estimated; and finally, the proxies will be included instead of barriers or blocks. All the models represent the results of the second stage of Heckman estimation model. In models $(0)-(12)$ the regional characteristics are considered, as well as all the discussed controls. Due to potential multicollinearity of regional education and network services expenditures with logarithms of GRP and regional retail trade volumes per capita, the latter two variables will be excluded from models (13) - (14). Hypotheses 1-10 will be tested on each sample separately.

\subsection{The first wave of study (2014)}

\section{Blocks}

Table 2 illustrates the estimation results for the baseline model (0) and three blocks of barriers (1) - (3). Model (4) will account for all the blocks jointly.

Table 2 goes here.

The baseline model (0) includes only merchant-specific and region-specific variables in order to obtain a general insight on the correlation between the share of merchants' cashless revenues and regional or firm-specific features. The estimation results are illustrated in Table 2. As could be seen from the results, no specific type or size of retailer has any evident significant variation in the effect on cashless revenue share on any reasonable significance level. The same conclusion could be applied to the assortment traded within the stores, as the coefficients for trading food and beverage, durables and clothing are not significant $(P$-values $>0,1)$. Therefore, the cashless revenue share does not significantly differ among retailers based on merchant-specific characteristics.

However, the estimates obtained for the merchants located in the Central $(-10,77)$, Siberian ($7,69)$ and North Caucasian/South $(-9,17)$ Federal Regions are significant at $5 \%, 10 \%$ and $10 \%$ significance levels correspondingly, which may not be interpreted straightforwardly as negative effect of locating in any of the above regions on cashless revenue share, though allows to compare the difference in potential cashless share drop between regions. Thus, merchants located in the Central Federal Region have, on average, 1,6 and 3,08 percentage points less of a cashless revenue share compared to the Far Eastern or Siberian correspondingly.

Moreover, having a location in a city with a population less than 100 thousand can significantly decrease the share of cashless revenue for a merchant by 7,2 percentage points, which seems intuitive regarding the cashless payments' integration, as sparsely populated cities are likely to be less developed (Bell \& Jayne, 2009).

Partaking in a retail trade chain or having a long-standing presence on the market does not show significant correlation with cashless revenue share, as well as the city of location being a regional 
center. The latter may be a result of a considerable number of large cities within all the regions, while the former two could be attributed to the rigidity of established merchants. Finally, the share of cashless revenue increases by 0,1 percentage point with $1 \%$ increase in GRP per capita, on average. The result is significant at $1 \%$ significance level. Retail trade volume per capita reveals not significant correlation. The above results are sustained with all other things held constant for each individual coefficient.

After the baseline model is discussed, we turn to the key models of the research. Models (1) - (3) include perception of each barrier block individually, while model (4) combines all three blocks. Models (5) and (6) account for actual effect of barriers through the usage of proxies.

Ceteris paribus, model (1) suggests that perception of higher human capital barriers of card acceptance results in approximately 9,86 percentage points decrease of merchant's cashless revenue share, on average. The obtained coefficient is significant at $5 \%$ significance level. This result supports the theoretical background behind the barrier: intuitively, merchants may perceive workers' underqualification as a moderate or major problem for cashless payments integration and maintenance within the store due to a variety of associated costs (Aboyasin \& A. F. Sultan, 2017; Chowdhury et al., 2014).

According to model (2), perception of higher infrastructural barriers (the quality of network connection and terminal malfunctions) shows a significant correlation with the share of cashless revenue when considered as a sole block at $10 \%$ significance level, and increases the corresponding share by 4,2 percentage points, on average. The obtained estimate goes in line with the theoretical predictions of the merchants' behavior when they consider infrastructural barriers as at least moderately stumbling.

Perception of higher institutional barriers alone does not reveal any significant effect on the cashless revenue share either ( $P$-value $>0,1)$. Therefore, there is not enough evidence in favor of inadequate bank/acquirer services or/and money transfer delays being eroding for cashless share of revenue, as perceived by merchants.

Model (4) allows us to consider all the blocks together, which eventuates into a slightly different results compared to the above. Perception of both human capital barriers and infrastructural barrier have significant negative effect on the share of cashless revenue of the merchant: on average, higher perceived human capital barriers decrease the share of cashless revenue by 10,5 percentage points, while at least moderate infrastructural barriers, as reported by the retailers, reduce the share by 4,38 percentage points. Results are significant at $5 \%$ and $10 \%$ significance levels correspondingly. Institutional barriers, however, again show no significance.

Models (1) - (4) presented in Table 2 additionally include variables accounting for internal and external merchants' environments: partaking in a loyalty program and the competitiveness of the market, expressed as dummies. The latter variables do not present any sign of significance ( $P$ value $=0,661$ ), however, the enrollment into a loyalty program of a bank/acquirer on average increases the share of cashless revenue by 10,7 percentage points with a significance on $1 \%$ significance level. A considerable bonus program effect may possibly be explained by a higher propensity of a merchant to promote cashless payments within the store if the loyalty scheme yields merchant fee discounts or other favorable features.

As the data is self-reported by the retailers, the intuition behind the outcome of model (4) regarding the acceptance barriers is ambiguous. On the one hand, the quality of banks' and/or acquirers' services to the merchants, as well as the speed of remittances, might be perceived as satisfactory for the merchants. On the other hand, the two remaining blocks of barriers could 
simply be more critical for the respondents, so they might have reported them as more disturbing, compared to the institutional one.

The joint significance test of three blocks above has yielded a chi-squared statistic of 8,38 and a $\mathrm{P}$-value of 0,0388 , revealing joint significance on $5 \%$ significance level. The result cannot be attributed to the multicollinearity, as all three variables considered have the correlations of less than $50 \%$ and some of the variables are significant solely. Having considered models (1)-(4), the study finds weak evidence in favor of hypotheses $1(\mathrm{H} 1)$ and hypotheses $2(\mathrm{H} 2)$ and rejects hypothesis 3 (H3) based on 2014 sample.

\section{Individual barriers}

Although the hypotheses regarding blocks of barriers have already been tested, it might be insightful to examine the significance of each barrier's perception individually in order to distinguish between the effects within the blocks. Table 3 summarizes the results of models (5)(11), with model (11) combining all the six barriers. As human capital is a unique barrier within the block, model (5) will coincide with model (1), as well as the obtained estimates, and only infrastructural and institutional barriers will be investigated further.

Table 3 goes here.

According to model (6), perception of poor connection quality as a moderate or major problem for accepting cards significantly reduces the share of cashless revenue by 3,96 percentage points, yielding P-value of 0,079 . Model (7), however, there is no significant effect observed in case of acquiring terminal breakages' perception with $P$-value of 0,145 . This partly coincides with the results obtained in model (2). Perceiving bank/acquirer support or delays in remittances as a substantial barrier for card acceptance within the store has revealed to be not significant at any reasonable significance level with $\mathrm{P}$-values of $0,357,0,713$ and 0,405 correspondingly in models (8)-(10).

Model (11) accounts for perception of all six barriers individually. Similar to the previous outcomes, the only significant variables are perceptions of higher human capital and connection quality barriers, with the former decreasing the cashless revenue share by 10,91 percentage points and the latter - by 4,46 percentage points. Corresponding P-values are 0,014 and 0,075. The remaining three barriers are not significant at any reasonable significance level. Variables are jointly significant at $10 \%$ significance level, with chi-squared value of 12,52 and P-value of 0,0514 . Therefore, the paper additionally finds the weak evidence for hypothesis $4(\mathrm{H} 4)$ and rejects the hypotheses 5-8 $(\mathrm{H} 5-\mathrm{H} 8)$ based on 2014 sample.

However, perception of barriers in general could also be a topic of interest. Although the respondents have not directly been asked about their perception of acceptance barriers overall, we are able to construct an index of binary variables (dummies) for blocks of barriers using the Principle Component Analysis. However, PCA-based index has not managed to yield a significant coefficient ( $P$-value $>0,1$ ). This could be interpreted as the lack of evidence in support of hypothesis 9 (H9) of negative barriers' perception effect on the share of merchant's cashless revenue based on 2014 sample. The estimation outcome is illustrated in model (12).

\section{Proxies and rationality}

The estimation output for the models considering proxies for human capital (model (13)) and infrastructural barriers (model (14)) within the region is presented in Table 4. Two proxies will not be tested jointly due to multicollinearity.

Table 4 goes here. 
Model (13) suggests that the share of yearly university graduates to regional population does not have a significant correlation with the share of merchants' cashless revenues at any reasonable significance level (P-value $=0,418)$. However, model (14) illustrates that 1 thousand rubles per capita increase in volume of regional network services increases the share of merchants' cashless revenue by 0,6 percentage points, with the corresponding coefficient significant at $10 \%$ significance level.

As a result of models (1) and (13) estimation, the proxy for human capital in a form of regional university graduates-to-population ratio does not yield a significant coefficient, while the merchants perceive human capital barriers as significant ones for determining the share for cashless revenue. Therefore, the rationality of merchants with respect to workers' qualification barrier cannot be supported.

Now let us analyze the output of the models, which consider infrastructural barriers. Perception of higher acquiring terminal malfunctioning barriers does not significantly affect the share of cashless revenue according to model (7). Nevertheless, estimation results of models (2), (4), (6) and (11) suggest that there is a significant effect of connection quality perception (and infrastructural barriers in general) on the cashless revenue on $10 \%$ significance level. Intuitively, higher regional expenditure on network services within the region last year increases the probability that the connection within the region will be stable and prompt this year. Thus, the operations within the store will be conducted timely, mitigating queues, transaction processing time and cashless payments availability in general and vice versa. Knowing that, the merchant may rationally associate poor connection quality with a lower share of cashless revenue.

The abovementioned logic suggests that the sign of the corresponding coefficients for perception of connection quality and infrastructural barriers in models (2), (4), (6), (11) should be negative, while in model (14) is should be positive, all of which holds. However, the coefficients cannot be compared by the absolute value ( 3 out of 4 models consider dummies) and they breach different significance levels (10\% and 5\%). Moreover, model (4) considers inclusion of one more variable into the infrastructural block of barriers, which is not significant based on model (11) estimation results. Having considered all the arguments above, there has been found only a weak evidence for merchants' rationality regarding the infrastructural barriers and connection quality effect on cashless revenue share.

Given the rationality of merchants with respect to human capital and institutional barriers cannot be substantiated due to variation in significance or the absence of representative proxy and provided only the infrastructural barriers effect on cashless revenue share is weakly supported by the estimated results, the paper rejects the hypothesis $10(\mathrm{H} 10)$ based on 2014 sample.

\subsection{The second wave of study (2017)}

\section{Blocks}

Tables 5 presents illustrates the estimation results for the baseline model (0) and three blocks of barriers (1) - (3) based on the sample for 2017. Model (4) will account for all the blocks jointly.

Table 5 goes here.

The baseline model (0) again considers only merchant-specific and region-specific variables. The estimation results are illustrated in Table 5. Contrary to the results of 2014 baseline model, there is a significant negative correlation between the merchant being a specialized food retailer or pharmacy and share of cashless revenue: $-6,83$ and $-9,75$ percentage points respectively with 
$1 \%$ significance. However, no significant effect of partaking in a retail chain, assortment or company size is observed.

According to the estimation results, only location in the Central Federal Region has a significant negative correlation with the cashless share (10,66 percentage points). Moreover, firm situated in the cities with population below 100 thousand people again significantly observe a fall of merchants' cashless revenue share by 12,44 percentage points, on average. Finally, the $1 \%$ increase in GRP per capita increases the cashless share by 0,55 percentage points, with a result significant on $10 \%$ significance level.

Contrary to the results obtained based on the previous wave, model (1) estimation output does not provide significant evidence in favor of higher perceived human capital barriers' negative effect on the share of cashless revenue. Perception of higher infrastructural barriers included in model (2), on the other hand, decreases the cashless revenue share by 5,09 percentage points on $5 \%$ significance level.

Notably, perception of higher institutional barriers significantly decreases the share of cashless revenue by 5,81 percentage points on $5 \%$ significance level $(P$-value $=0,045)$. This supports the theoretical mechanism related to perception of bank-merchant and acquirer-merchant relationships, as well as the speed of remittances, on the non-cash revenue share. In order to investigate the issue further, perception each barrier within the block will be examined separately after the model (4) is estimated.

Based on the estimation result of model (4), the outcome of models (1) - (3) is sustained in a joint model. Perception of higher infrastructural and institutional barriers significantly reduces merchants' non-cash revenue share by 4,49 and 4,92 percentage points correspondingly on $10 \%$ significance level. Perception of higher human capital barriers reveals no significant negative effect of cashless share, while the result for infrastructural barriers goes in line with the estimation on 2014 sample.

Joint significance test has yielded the chi-squared statistic value of 7,49 and $P$-value of 0,0578 , rejecting the hypothesis of joint insignificance of blocks' perceptions on $10 \%$ significance level. The PCA-based index is used to construct a dummy reflecting the perception of higher barriers in general. The index has proven to be significant at $5 \%$ significance level, as could be retrieved from the Table 5. Having considered models (1)-(4), the study finds weak evidence in favor of hypotheses $2(\mathrm{H} 2)$ and hypotheses $3(\mathrm{H} 3)$ and rejects hypothesis $1(\mathrm{H} 1)$ based on 2017 sample.

\section{Individual barriers}

Table 6 summarizes the estimation results of models (5)-(11), which allows to see the effect of perception of each barrier individually as well as jointly in model (11). Models (1) and (5) coincide due to the single barrier included into the human capital block.

Table 6 goes here.

Model (6) estimation reveals no significant effect of higher connection quality barrier perception on merchants' cashless revenue share. However, according to model (7), perception of terminal malfunctioning as a high barrier for card acceptance decreases the share of cashless revenue by 13,04 percentage points on $1 \%$ significance level. This allows us to deconstruct the infrastructural barrier perception effect and underline the dominating effect associated with perception of equipment breakdowns. Although the first sample has indicated the significance of perception of the other barrier in the group, overall the effect is consistent among the datasets regarding the infrastructural block. 
According to models (8) - (9), perception of neither higher bank-related nor higher acquirerrelated issues as of a major problem for cashless payments integration within the store has indicated a significant effect on the non-cash revenue share, which is also consistent with the estimation based on the first sample. However, perception of higher barriers associated with the remittances delays becomes significant on $5 \%$ significance level, contrary to the previous estimation, and decreases the cashless revenue share of merchant by 7,3 percentage points, on average. The results are obtained based on model (10).

Overall, the significance of individual barriers' perceptions remains in model (11) for all the coefficients expect for connection quality, which becomes significant at $5 \%$ significance level, indicating the adverse effect of 5,44 percentage points on the cashless share. Joint significance test yields a P-value of $\sim 0$, while the PCA-based index of barriers (not blocks) also shows significance at $10 \%$ significance level (see model (12)). Hence, the study finds the weak evidence for hypotheses $4(\mathrm{H} 4), 5(\mathrm{H} 5), 8(\mathrm{H} 8)$ and $10(\mathrm{H} 10)$ and rejects the hypotheses 6-7 $(\mathrm{H} 6-\mathrm{H} 7)$ based on 2017 sample.

\section{Proxies and rationality}

Table 7 shows the results for estimation of the remaining models (13) and (14), which consider the proxies for human capital and infrastructural barriers correspondingly. For the same reason of possible multicollinearity, logarithms of GRP and retail trade volume per capita are excluded from the estimated models.

Table 7 goes here.

The obtained results are fully consistent with the estimation of corresponding models based on the 2014 sample. The share of university graduates-to-population within the region does not yield significant effect on the share of merchants' cashless revenue, while the one thousand rubles increase volume of regional network services per capita extends the non-cash share of revenue by 0,69 percentage points, on average. No proxy for institutional effect was applied.

The rationality of merchants regarding the infrastructural barriers effect on cashless revenue coincides with the result obtained based on the first wave of study, while no conclusion on rationality regarding institutional barriers can be made with at least some degree of certainty. As for the human capital block, the results of models (1), (4) and (13) should be assessed to draw the coherent conclusion.

On the one hand, the number of university graduates per capita on a regional level does not show significant correlation with the share of non-cash revenues for retailers. On the other hand, the perception of higher human capital barriers has yielded no significant effect on the dependent variable either. Rejection of hypothesis (1) may be interpreted as follows. When the merchant perceives workers' underqualification barrier as a major issue for cashless payments integration and maintenance, his consequent actions (e.g. reluctant search for employees or their training) do not significantly reduce the share of cashless revenue. Although both the educational proxy and the merchant actions in underpromotion of card acceptance do not have a significant effect on the cashless revenue share, the retailer can hardly be seen as rational.

Overall, the rationality of merchants can only be supported with respect to only one block of barriers out of three. Despite the consistency of conclusion regarding infrastructural barriers in both samples, the study rejects the hypothesis 10 (H10) based on 2017 sample. Despite the consistency of conclusion regarding infrastructural barriers in both samples, there is not enough evidence in favor of merchants' rationality. 


\section{Conclusion}

The paper examines the perception of card acceptance barriers and its effect on cashless revenue share based on two representative samples of Russian merchants in 2014 and 2017. Perception of higher infrastructural barriers was found to be the only result, which is significant and consistent at the same time in its negative effect on the share of retailers' non-cash revenues. Perception of higher institutional barriers, as well as human capital barriers has only proven to have significant effect in the models based on 2017 and 2014 correspondingly. The PCA-based index of barriers' perception has allowed to find a weak evidence for its negative effect on the cashless revenue share.

The actual barriers' effect on the cashless revenues was estimated with the application of two proxies: the number of university graduates per capita within the region and the average regional network services volumes. The latter revealed significantly positive effect, while the former fail to indicate significance on both samples.

Due to the difference in the perceived and actual results with respect to acceptance barriers' effect on non-cash revenue share, the conclusion about the merchants' rationality cannot be claimed with certainty, with an only evidence found for infrastructural block of barriers. However, perception of each of the mentioned blocks has proven to be significant during the study, while the actual effect kept its significance only for the network services volume, which could reveal some use for practical implications.

Not only the results for each individual barrier or its perception may be taken into account by the regulator or retailers themselves - with a more consistent perceived effect on the cashless share of revenue, introduced policies aiming to smooth the barrier appear should also be targeted upon the perception of these barriers as well. Moreover, estimation results may serve as useful indicators for merchants to form the expectations in line with the actual effects.

All the obtained results may be claimed robust based on the similarity in significance of key explanatory variables in a series of specifications used in the study. Although the perception of various barriers does not maintain the same significance over the two samples considered, the differences could be attributed to a series of government actions regarding the acceptance barriers. According to the Ministry of Finance statistics on the federal budget, government expenditures on education have increased by $13 \%$ for $2013-2017$ period, which could have affected the significance of perception about human capital barriers among merchants in the second wave. Significance of perception about higher infrastructural barriers effect on cashless revenue share has remained over the samples, with merchants' concern switched into the direction of equipment breakdowns. Higher institutional barriers, as perceived by the retailers, have reached significance in their negative influence on cashless share based on the second sample estimation, which could potentially be explained by the attention shift from workers' underqualification barrier or increased complaints about delays in remittances in 2017.

Moreover, an attempt to mitigate potential endogeneity caused by omitted controls was made by the inclusion of regional characteristics into the models. Figures for GRP per capita and retail trade volumes per capita, as well as the abovementioned regional proxies, are also accounted for with a lag of one year to mitigate potential problems of reverse causality.

The study contributes to the existing literature (Arango \& Taylor, 2008a; Arango, P. Huynh, \& Sabetti, 2015; Arango-Arango, Bouhdaoui, Bounie, Eschelbach, \& Hernandez, 2018; Bolt \& Chakravorti, 2008; Borestam \& Schmiedel, 2011; Kim et al., 2010; Krivosheya \& Korolev, 2016, 2018; Loke, 2007; Mimouni-Chaabane \& Volle, 2010; Rochet \& Tirole, 2002, 2003, 2011; 
Rysman, 2007; Weiner \& Wright, 2005) by examining both the perceived and actual effect of barriers on merchants' cashless revenues share. Moreover, the regional characteristics of retailers are taken into account. The conducted analysis allows to differentiate the effects associated with each barrier individually, as well as to assess the joint effect. Finally, the paper attempts to assess merchants' rationality with respect to acceptance barriers.

The results of this paper could potentially be utilized by the regulatory authorities and merchants themselves, enabling both to spot significant factors affecting the acceptance and promotion of cashless payments and to aline the actions on obtaining the maximum total surplus on the market. Understanding the effect of own attitude on the cashless revenue may induce retailers to reformulate their actions in a most commercially beneficial way. Moreover, the results obtained may highlight the major barriers for cashless economy integration, setting a new agenda for the regulators aiming to reduce the frictions.

In the further research on the topic of cashless payments market, merchants' perception of barriers and the actual effect of these barriers on cashless revenue could be estimated in dynamics, for which the structure of the used dataset has not allowed. Moreover, the rationality of all groups of market participants could be assessed in order to aline the actions of all related parties. The regional or merchant-level proxies for institutional barriers would allow to make a concise evaluation of retailers' rationality with respect to acceptance barriers in general. A series of other regional characteristics could also be used to properly account for the location features of the retailers. Finally, the cross-county analysis could be conducted to track the variation of perceptual and actual effects of acceptance barriers with respect to national features. In a perspective, this might allow regulatory authorities to update their policy on digital economy diffusion based on important national characteristics in order to boost the overall country development.

\section{References}

1. Aboyasin, N., \& A. F. Sultan, M. (2017). The Role of Human Resources Training in Improving the Employee's Performance: Applied Study in the Five Stars Hotels in Jordan. International Journal of Business Administration, 8, 46. https://doi.org/10.5430/ijba.v8n5p46

2. Arango, C., P. Huynh, K., \& Sabetti, L. (2015). Consumer Payment Choice: Merchant Card Acceptance versus Pricing Incentives. Journal of Banking \& Finance, 55. https://doi.org/10.1016/j.jbankfin.2015.02.005

3. Arango, C., \& Taylor, V. (2008a). Merchant acceptance, costs, and perceptions of retail payments: A Canadian survey (Working Paper No. 2008-12). Retrieved from Bank of Canada Discussion Paper website: https://www.econstor.eu/handle/10419/66914

4. Arango, C., \& Taylor, V. (2008b). Merchants' Costs of Accepting Means of Payment: Is Cash the Least Costly? Bank of Canada Review, 2008-2009(Winter), 17-25.

5. Arango-Arango, C. A., Bouhdaoui, Y., Bounie, D., Eschelbach, M., \& Hernandez, L. (2018). Cash remains top-of-wallet! International evidence from payment diaries. Economic Modelling, 69, 38-48. https://doi.org/10.1016/j.econmod.2017.09.002 
6. Bahamonde-Birke, F. J., Kunert, U., Link, H., \& Ortúzar, J. de D. (2017). About Attitudes and Perceptions: Finding the Proper Way to Consider Latent Variables in Discrete Choice Models. https://doi.org/10.2139/ssrn.2603218

7. Bao, T., Hommes, C. H., Sonnemans, J., \& Tuinstra, J. (2012). Individual Expectations, Limited Rationality and Aggregate Outcomes (SSRN Scholarly Paper No. ID 2007137). Retrieved from Social Science Research Network website: https://papers.ssrn.com/abstract $=2007137$

8. Bell, D., \& Jayne, M. (2009). Small cities? Towards a research agenda. International Journal of Urban and Regional Research, 33, 683-699.

9. Bolt, W., \& Chakravorti, S. (2008). Economics of payment cards: a status report. Economic Perspectives, (Q IV), 15-27.

10. Borestam, A., \& Schmiedel, H. (2011). Interchange Fees in Card Payments.

11. Bounie, D., François, A., \& Van, H. L. (2016). Merchant Acceptance of Payment Cards: "Must Take" or "Wanna Take"? Review of Network Economics, 15(3), 117-146. https://doi.org/10.1515/rne-2017-0011

12. Carbó-Valverde, S., Liñares-Zegarra, J. M., \& Rodríguez-Fernández, F. (2012). Feedback Loop Effects in Payment Card Markets: Empirical Evidence. Review of Network Economics, 11(2). https://doi.org/10.1515/1446-9022.1268

13. Certo, S. T., Busenbark, J. R., Woo, H., \& Semadeni, M. (2016). Sample selection bias and Heckman models in strategic management research. Strategic Management Journal, 37(13), 2639-2657. https://doi.org/10.1002/smj.2475

14. Chowdhury, S., Schulz, E., Milner, M., \& Van De Voort, D. (2014). Core employee based human capital and revenue productivity in small firms: An empirical investigation. Journal of Business Research, 67(11), 2473-2479. https://doi.org/10.1016/j.jbusres.2014.03.007

15. Clark, S. J., \& Houle, B. (2014). Validation, Replication, and Sensitivity Testing of HeckmanType Selection Models to Adjust Estimates of HIV Prevalence. PLoS ONE, 9(11). https://doi.org/10.1371/journal.pone.0112563

16. Goldberger, A. S. (1983). Abnormal selection bias. Studies in Econometrics, Time Series, and Multivariate Statistics.

17. Hanushek, E. A. (2013). Economic growth in developing countries: The role of human capital. $\begin{array}{llll}\text { Economics of } & \text { Education }\end{array}$ https://doi.org/10.1016/j.econedurev.2013.04.005

18. Heckman, J. J. (1976). The Common Structure of Statistical Models of Truncation, Sample Selection and Limited Dependent Variables and a Simple Estimator for Such Models. Annals of Economic and Social Measurement, Volume 5, Number 4, 475-492.

19. Hermann, M., Pentek, T., \& Otto, B. (2016, January 1). Design Principles for Industrie 4.0 Scenarios. 3928-3937. https://doi.org/10.1109/HICSS.2016.488

20. Hommes, C. (2013). Behaviorally Rational Expectations and Almost Self-Fulfilling Equilibria (CeNDEF Working Paper No. 13-17). Retrieved from Universiteit van Amsterdam, Center for Nonlinear Dynamics in Economics and Finance website: https://econpapers.repec.org/paper/amsndfwpp/13-17.htm 
21. Kahneman, D. (1994). New Challenges to the Rationality Assumption. Journal of Institutional and Theoretical Economics (JITE) / Zeitschrift Für Die Gesamte Staatswissenschaft, 150(1), 18-36. Retrieved from JSTOR.

22. Kim, C., Tao, W., Shin, N., \& Kim, K.-S. (2010). An empirical study of customers' perceptions of security and trust in e-payment systems. Electronic Commerce Research and Applications, 9(1), 84-95. https://doi.org/10.1016/j.elerap.2009.04.014

23. Krivosheya, E. (2018). Network effects at retail payments market: evidence from Russian merchants. Proceedings of the 10th Economics \& Finance Conference, Rome, 288-322.

24. Krivosheya, E., \& Korolev, A. (2016). Benefits of the retail payments card market: Russian cardholders' evidence. Journal of Business Research, 69(11), 5034-5039. https://doi.org/10.1016/j.jbusres.2016.04.076

25. Krivosheya, E., \& Korolev, A. (2018). Benefits of the retail payments card market: Evidence from Russian merchants. Journal of Business Research, 88, 466-473.

26. Krivosheya, E., \& Semerikova, E. (2018). Network effects at retail payments market: evidence from Russian individuals. Proceedings of the 10th Economics \& Finance Conference, Rome, 254-287.

27. Krivosheya, E., Semerikova, E., Korolev, A. \& Tarusova, E. (2017). Cashless economy in Russia 2030: Scenarios for market and industry. Moscow School of Management SKOLKOVO Working Paper.

28. Loke, Y. J. (2007). Determinants of Merchant Participation in Credit Card Payment Schemes. Review of Network Economics, 6(4). https://doi.org/10.2202/1446-9022.1130

29. Lovell, M. C. (1986). Tests of the Rational Expectations Hypothesis. The American Economic Review, 76(1), 110-124.

30. Luthans, F., \& Youssef, C. M. (2004). Human, Social, and Now Positive Psychological Capital Management: Investing in people for competitive advantage. Organizational Dynamics, 33(2), 143-160. https://doi.org/10.1016/j.orgdyn.2004.01.003

31. Mandal, P. K. (2017). Problems and Prospects of Cashless India. Educreation Publishing.

32. Mimouni-Chaabane, A., \& Volle, P. (2010). Perceived benefits of loyalty programs: Scale development and implications for relational strategies. Journal of Business Research, 63(1), 32-37. https://doi.org/10.1016/j.jbusres.2009.01.008

33. Muth, J. F. (1961). Rational Expectations and the Theory of Price Movements. Econometrica, 29(3), 315. https://doi.org/10.2307/1909635

34. Nawata, K. (1994). Estimation of sample selection bias models by the maximum likelihood estimator and Heckman's two-step estimator. Economics Letters, 45(1), 33-40.

35. Nwankwo, O., \& Eze, O. R. (2013). Electronic Payment in Cashless Economy of Nigeria: Problems and Prospect. Journal of Management Research, 5(1), 138.

36. Puhani, P. (2000). The Heckman Correction for Sample Selection and Its Critique. Journal of Economic Surveys, 14(1), 53-68.

37. Rahim, A., Atan, R., \& Kamaluddin, A. (2017). Human Capital Efficiency and Firm Performance: An Empirical Study on Malaysian Technology Industry. SHS Web of Conferences, 36, 00026. https://doi.org/10.1051/shsconf/20173600026 
38. Rochet, J.-C., \& Tirole, J. (2002). Cooperation among Competitors: Some Economics of Payment Card Associations. The RAND Journal of Economics, 33(4), 549-570. https://doi.org/10.2307/3087474

39. Rochet, J.-C., \& Tirole, J. (2003). Platform Competition in Two-sided Markets. Journal of the European Economic Association, 1(4), 990-1029. Retrieved from JSTOR.

40. Rochet, J.-C., \& Tirole, J. (2011). Must-Take Cards: Merchant Discounts and Avoided Costs. Journal of the European Economic Association, 9(3), 462-495. https://doi.org/10.1111/j.15424774.2011.01020.x

41. Rysman, M. (2007). An Empirical Analysis of Payment Card Usage*. The Journal of Industrial Economics, 55(1), 1-36. https://doi.org/10.1111/j.1467-6451.2007.00301.x

42. Simon, H. (1990). Reason in Human Affairs. Stanford University Press.

43. Voges, K., \& Pulakanam, V. (2010, September 27). Factors Influencing Internet Adoption by Small and Medium Size Retail Enterprises in New Zealand.

44. Weiner, S., \& Wright, J. (2005). Interchange Fees in Various Countries: Developments and Determinants. Review of Network Economics, 4(4), 1-34.

45. Xu, X., Wong, S. C., Zhu, F., Pei, X., Huang, H., \& Liu, Y. (2017). A Heckman selection model for the safety analysis of signalized intersections. PLoS ONE, 12(7). https://doi.org/10.1371/journal.pone.0181544

46. Zwart-van Rijkom, J. E., Leufkens, H. G., Busschbach, J. J., Broekmans, A. W., \& Rutten, F. F. (2000). Differences in attitudes, knowledge and use of economic evaluations in decisionmaking in The Netherlands. The Dutch results from the EUROMET Project. PharmacoEconomics, 18(2), 149-160. https://doi.org/10.2165/00019053-200018020-00005

47. Операции, совершенные на территории России и за ее пределами с использованием платежных карт, эмитированных кредитными организациями, по видам клиентов. Центральный Банк Российской Федерации. Available online: https://www.cbr.ru/statistics/p_sys/print.aspx?file=sheet014_1.htm\&pid=psrf\&sid=ITM_48796

48. Операции, совершенные на территории России с использованием платежных карт эмитентов-резидентов и нерезидентов. Центральный Банк Российской Федерации. Available online:

49. https://www.cbr.ru/statistics/p_sys/print.aspx?file=sheet015.htm\&pid=psrf\&sid=ITM_47378

50. Развитие интернета в регионах России, 2016. Исследования Яндекса. Available online:

51. https://yandex.ru/company/researches/2016/ya_internet_regions_2016

52. Рынок розничных электронных средств платежа 2017. Аналитический центр НАФИ. Available online:

53. https://nafi.ru/upload/iblock/0c5/0c59187fb8c98297148c19ee37cbdce1.pdf

54. Регионы России. Социально-экономические показатели - 2017 г. Федеральная служба государственной статистики. http://www.gks.ru/bgd/regl/B17_14p/Main.htm

Available online:

55. Annual report on execution of the federal budget (starting from January 1, 2006). Ministry of Finance of the Russian Federation. Available online: https://www.minfin.ru/en/statistics/fedbud/ 
56. Financial innovations and cashless economy center. Retail payments study 2017. Moscow School of Management SKOLKOVO. Available online: https://finance.skolkovo.ru/ru/sfice/research-reports/1653-2018-08-10/

57. World Payments Report 2018. Capgemini and BNP Paribas. Available online: https://worldpaymentsreport.com/non-cash-payments-volume/\#non-cash-transactionsglobally-regionally

\section{$7 \quad$ Appendix}

Table 1-1. Descriptive Statistics, 2014

\begin{tabular}{|c|c|c|c|c|}
\hline Variable & Mean & Std.Dev. & Min & $\operatorname{Max}$ \\
\hline Cashless share & 25.572 & 15.434 & $\overline{0}$ & 70 \\
\hline Hypermarket & .062 & .241 & 0 & 1 \\
\hline Specialized (food) & .048 & .215 & 0 & 1 \\
\hline $\begin{array}{l}\text { Specialized (non- } \\
\text { food) }\end{array}$ & .136 & .344 & 0 & 1 \\
\hline Kiosk, stall & .351 & .478 & 0 & 1 \\
\hline Pharmacy & .073 & .261 & 0 & 1 \\
\hline Retail trade chain & .246 & .431 & 0 & 1 \\
\hline Central FR & .184 & .387 & 0 & 1 \\
\hline Northwestern FR & .135 & .342 & 0 & 1 \\
\hline North FR & .153 & .36 & 0 & 1 \\
\hline Volga FR & .163 & .369 & 0 & 1 \\
\hline $\begin{array}{l}\text { North Cauc./South } \\
\text { FR }\end{array}$ & .124 & .33 & 0 & 1 \\
\hline Far Eastern FR & .112 & .315 & 0 & 1 \\
\hline Over $1 \mathrm{~m}$ pop. & .376 & .485 & 0 & 1 \\
\hline $\begin{array}{l}\text { Between } 500 \mathrm{k} \text { and } \\
1 \mathrm{~m} \text { pop. }\end{array}$ & 149 & .356 & 0 & 1 \\
\hline $\begin{array}{l}\text { Less than } 100 \mathrm{k} \\
\text { pop. }\end{array}$ & .15 & .357 & 0 & 1 \\
\hline Market presence & 7.186 & 6.263 & 0 & 54 \\
\hline $\begin{array}{l}\text { Food and } \\
\text { beverage }\end{array}$ & .548 & .498 & 0 & 1 \\
\hline
\end{tabular}




\begin{tabular}{|c|c|c|c|c|c|}
\hline Durables & .05 & & .217 & 0 & 1 \\
\hline Clothing & .115 & & .32 & 0 & 1 \\
\hline Acquiring fee & 1.755 & & .633 & .02 & 3.2 \\
\hline Loyalty program & .033 & & .18 & 0 & 1 \\
\hline Competitive threat & .311 & & .463 & 0 & 1 \\
\hline Regional center & .592 & & .492 & 0 & 1 \\
\hline $\begin{array}{l}\text { Ln (GRP per } \\
\text { capita) }\end{array}$ & 5.769 & & .492 & 5.038 & 7.172 \\
\hline $\begin{array}{l}\text { Ln (Retail vol. per } \\
\text { capita) }\end{array}$ & 5.095 & & .241 & 4.571 & 5.633 \\
\hline $\begin{array}{l}\text { 10-100m RUB } \\
\text { turnover }\end{array}$ & .218 & & .413 & 0 & 1 \\
\hline $\begin{array}{l}\text { 1-10m RUB } \\
\text { turnover }\end{array}$ & .311 & & .463 & 0 & 1 \\
\hline$<1 \mathrm{~m}$ RUB turnover & .117 & & .321 & 0 & 1 \\
\hline $\begin{array}{l}\text { Human capital } \\
\text { barriers }\end{array}$ & .042 & & .2 & 0 & 1 \\
\hline $\begin{array}{l}\text { Infrastructural } \\
\text { block }\end{array}$ & .16 & & .367 & 0 & 1 \\
\hline Institutional block & .034 & & .182 & 0 & 1 \\
\hline Connection barrier & .032 & & .176 & 0 & 1 \\
\hline $\begin{array}{l}\text { Equip. breakages } \\
\text { barrier }\end{array}$ & .029 & & .169 & 0 & 1 \\
\hline $\begin{array}{l}\text { Bank support } \\
\text { barrier }\end{array}$ & .054 & & .226 & 0 & 1 \\
\hline $\begin{array}{l}\text { Acquiring support } \\
\text { barrier }\end{array}$ & .177 & & .382 & 0 & 1 \\
\hline $\begin{array}{l}\text { Remit. speed } \\
\text { barrier }\end{array}$ & .076 & & .266 & 0 & 1 \\
\hline $\begin{array}{l}\text { No. of uni. grad-s } \\
\text { per capita }\end{array}$ & .981 & & .38 & .119 & 1.863 \\
\hline $\begin{array}{l}\text { Network services } \\
\text { vol. }\end{array}$ & 9.496 & 5.546 & & 1.859 & 24.935 \\
\hline
\end{tabular}

Source: Author's calculations 
Table 1-2. Descriptive Statistics, 2017

\begin{tabular}{|c|c|c|c|c|}
\hline Variable & Mean & Std.Dev. & Min & $\operatorname{Max}$ \\
\hline Cashless share & 39.286 & 18.048 & 2 & 90 \\
\hline Hypermarket & .076 & .266 & 0 & 1 \\
\hline Specialized (food) & .25 & .433 & 0 & 1 \\
\hline $\begin{array}{l}\text { Specialized (non- } \\
\text { food) }\end{array}$ & .01 & .102 & 0 & 1 \\
\hline Kiosk, stall & .277 & .448 & 0 & 1 \\
\hline Pharmacy & .064 & .246 & 0 & 1 \\
\hline Retail trade chain & .313 & .464 & 0 & 1 \\
\hline $\begin{array}{l}\text { Food and } \\
\text { beverage }\end{array}$ & .26 & .439 & 0 & 1 \\
\hline Durables & .03 & .171 & 0 & 1 \\
\hline Clothing & .01 & .102 & 0 & 1 \\
\hline $\begin{array}{l}10-100 \mathrm{~m} \text { RUB } \\
\text { turnover }\end{array}$ & .121 & .327 & 0 & 1 \\
\hline $\begin{array}{l}1-10 \mathrm{~m} \text { RUB } \\
\text { turnover }\end{array}$ & .275 & .447 & 0 & 1 \\
\hline$<1 \mathrm{~m}$ RUB turnover & .359 & .48 & 0 & 1 \\
\hline Loyalty program & .189 & .392 & 0 & 1 \\
\hline Acquiring fee & 2.015 & 2.436 & .1 & 30 \\
\hline Competitive threat & .265 & .442 & 0 & 1 \\
\hline Market presence & 3.484 & 3.043 & 0 & 17 \\
\hline Volga FR & .15 & .357 & 0 & 1 \\
\hline North FR & .145 & .353 & 0 & 1 \\
\hline $\begin{array}{l}\text { North Cauc./South } \\
\text { FR }\end{array}$ & .153 & .36 & 0 & 1 \\
\hline Far Eastern FR & .121 & .327 & 0 & 1 \\
\hline Central FR & .189 & .392 & 0 & 1 \\
\hline Northwestern FR & .124 & .33 & 0 & 1 \\
\hline
\end{tabular}




\begin{tabular}{|c|c|c|c|c|}
\hline Over 1m pop. & .216 & .412 & 0 & 1 \\
\hline $\begin{array}{l}\text { Between } 500 \mathrm{k} \text { and } \\
1 \mathrm{~m} \text { pop. }\end{array}$ & .183 & .387 & 0 & 1 \\
\hline $\begin{array}{l}\text { Less than } 100 \mathrm{k} \\
\text { pop. }\end{array}$ & .407 & .492 & 0 & 1 \\
\hline Regional center & .445 & .497 & 0 & 1 \\
\hline $\begin{array}{l}\text { Ln (GRP per } \\
\text { capita) }\end{array}$ & 13.055 & .547 & 12.257 & 14.432 \\
\hline $\begin{array}{l}\text { Ln (Retail vol. per } \\
\text { capita) }\end{array}$ & 12.174 & .237 & 11.568 & 12.756 \\
\hline Connection barrier & -.176 & .381 & 0 & 1 \\
\hline $\begin{array}{l}\text { Equip. breakages } \\
\text { barrier }\end{array}$ & .095 & .294 & 0 & 1 \\
\hline $\begin{array}{l}\text { Human capital } \\
\text { barriers }\end{array}$ & .017 & .128 & 0 & 1 \\
\hline $\begin{array}{l}\text { Bank support } \\
\text { barrier }\end{array}$ & .038 & .192 & 0 & 1 \\
\hline $\begin{array}{l}\text { Acquiring support } \\
\text { barrier }\end{array}$ & .031 & .173 & 0 & 1 \\
\hline $\begin{array}{l}\text { Remit. speed } \\
\text { barrier }\end{array}$ & .098 & .297 & 0 & 1 \\
\hline $\begin{array}{l}\text { Infrastructural } \\
\text { block }\end{array}$ & .193 & .395 & 0 & 1 \\
\hline Institutional block & .131 & .338 & 0 & 1 \\
\hline $\begin{array}{l}\text { No. of uni. grad-s } \\
\text { per capita }\end{array}$ & .789 & .366 & .14 & 1.77 \\
\hline $\begin{array}{l}\text { Network services } \\
\text { vol. }\end{array}$ & 9.412 & 5.159 & 1.939 & 24.987 \\
\hline
\end{tabular}

Source: Author's calculations 
Panel 1. Cross-correlation matrix, 2014

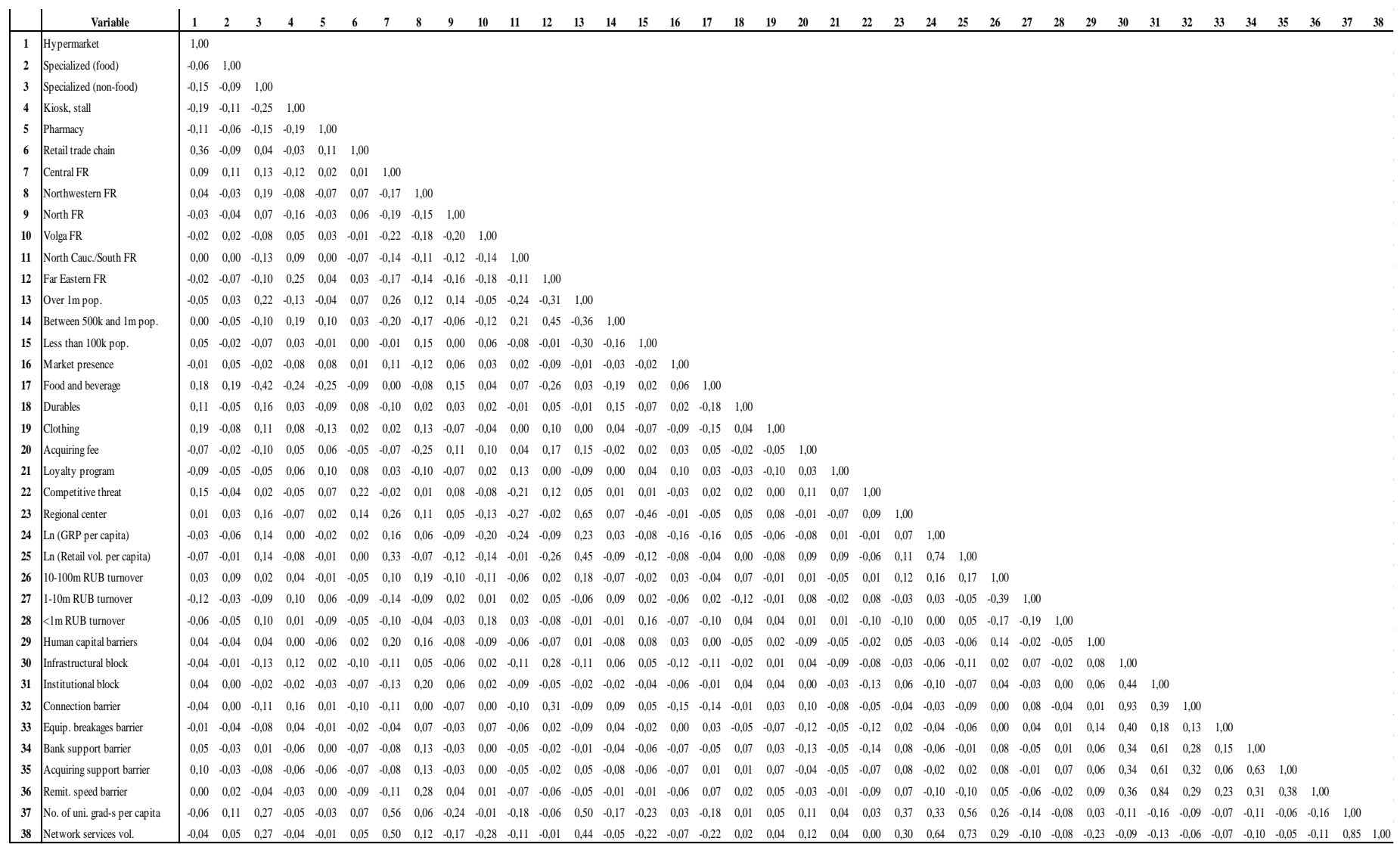

Source: Author's calculations

Panel 2. Cross-correlation matrix, 2017

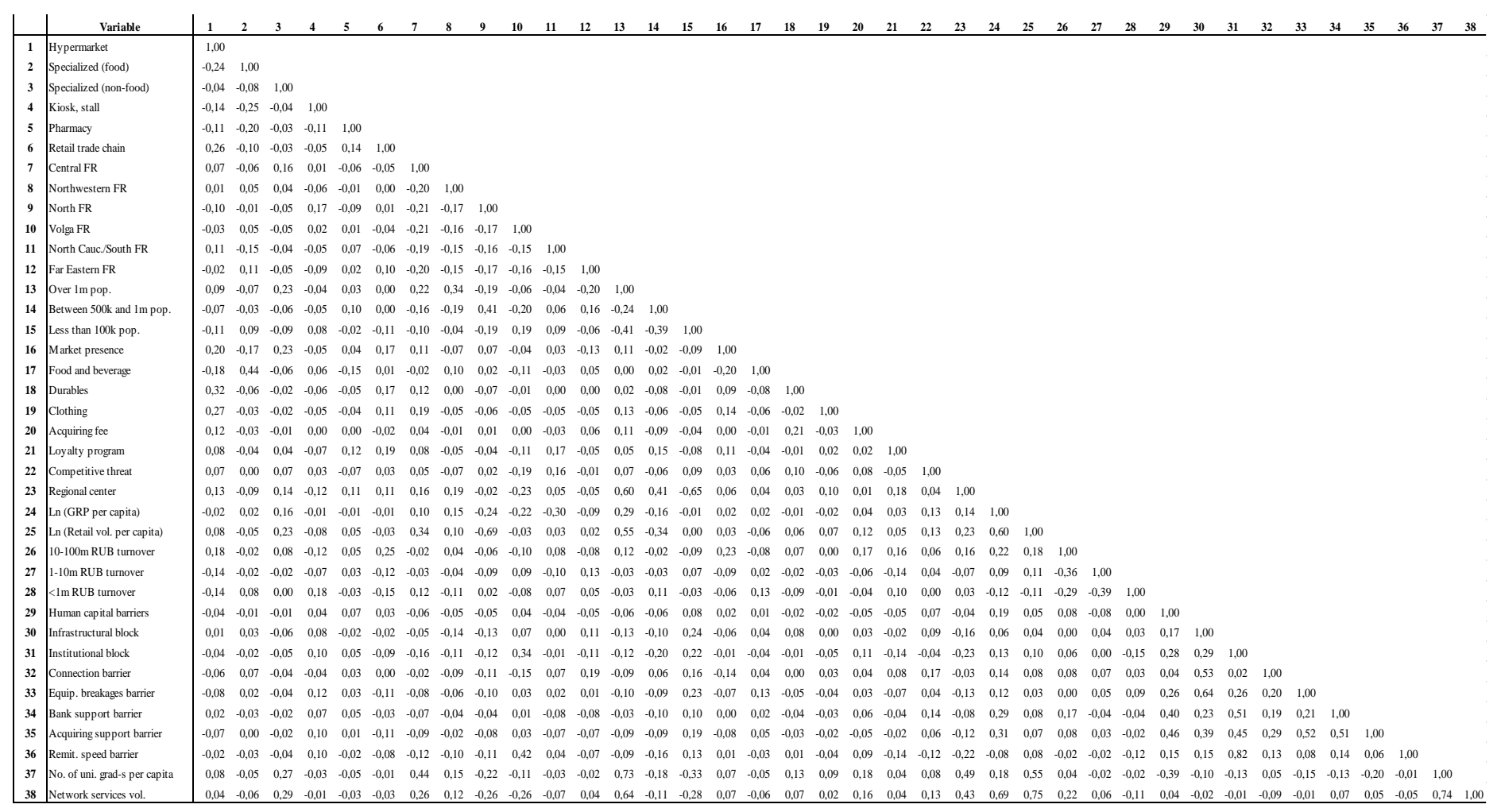

Source: Author's calculations 
Table 2. Perception of higher acceptance barriers (in blocks) and its effect on merchant's cashless revenue share, 2014

(0)

Variables

Hypermarket

Specialized (food)

Kiosk, stall

Pharmacy

Retail trade chain

Central FR

Northwestern FR

North FR

Volga FR

$-3.869$

(3.183)

North Caucasian/South

FR

Far Eastern FR

$$
\begin{aligned}
& -9.137^{*} \\
& (5.309)
\end{aligned}
$$

$-4.864$
Baseline

(1) model
6.301

(4.325)

$-3.550$

(5.118)

3.302

(3.539)

$-6.512$

(5.266)

$-2.269$

(3.839)

7.983

(5.833)

$-8.948^{\star}$

(4.736)

$-8.062$

(6.516)

$-7.903$

(4.933)

$-4.469$

(3.501)

(3.491)

$-11.44^{*}$

(6.335)

(6.310)

$-6.397$

6.185

(4.322)

$-2.661$

(5.100)

4.064

(3.563)

$-6.395$

(5.263)

$-1.522$

(3.827)

7.893

(5.825)

(4.662)

$-8.770$

(6.493)

$-7.641$

(4.925)

$-4.305$

$-12.48^{\star *}$

$-6.557$
(2)

(3)

Infrastructural block

6.545

6.091

(4.407)

(4.252)

$-2.687$

$-3.456$

(5.166)

(5.036)

3.354

4.086

(3.593)

(3.498)

$-6.663$

$-6.161$

(5.337)

(5.164)

$-1.783$

$-2.072$

(3.889)

(3.762)

7.994

7.761

(5.910)

(5.719)

$-10.59^{* *}$

$-10.73^{\star \star}$

$-8.821^{*}$

(4.740)

(4.660)

$-9.056$

$-7.502$

(6.590)

(6.390)

$-7.730$

$-7.669$

(5.000)

(4.838)

$-4.161$

$-4.674$

(3.546)

(3.429)

$-12.22^{\star}$

$-11.87^{\star}$
(6.240)

$-7.730$ 


\begin{tabular}{|c|c|c|c|c|c|}
\hline & (4.382) & $(4.830)$ & $(4.830)$ & (4.892) & $(4.791)$ \\
\hline \multirow[t]{2}{*}{ Over $1 \mathrm{~m}$ population } & -2.198 & 1.683 & 1.475 & 2.013 & 0.902 \\
\hline & $(4.113)$ & $(4.748)$ & $(4.753)$ & $(4.808)$ & $(4.676)$ \\
\hline \multicolumn{6}{|l|}{ Between $500 \mathrm{k}$ and $1 \mathrm{~m}$} \\
\hline \multirow[t]{2}{*}{ pop } & 2.763 & 5.999 & 5.650 & 5.878 & 5.747 \\
\hline & (3.514) & $(4.018)$ & $(4.017)$ & $(4.073)$ & (3.944) \\
\hline \multicolumn{6}{|l|}{ Less than $100 \mathrm{k}$} \\
\hline population & (3.612) & $(3.811)$ & $(3.805)$ & $(3.861)$ & $(3.755)$ \\
\hline \multirow[t]{2}{*}{ Market presence (years) } & -0.0529 & -0.100 & -0.0896 & -0.103 & -0.0862 \\
\hline & $(0.145)$ & $(0.165)$ & $(0.165)$ & $(0.167)$ & $(0.163)$ \\
\hline \multirow[t]{2}{*}{ Food and beverage } & -0.799 & -2.658 & -2.107 & -2.692 & -2.072 \\
\hline & $(2.910)$ & (3.041) & (3.062) & (3.095) & $(3.010)$ \\
\hline \multirow[t]{2}{*}{ Durables } & 6.346 & 6.876 & 7.109 & 7.218 & 6.759 \\
\hline & $(3.916)$ & $(4.370)$ & $(4.356)$ & $(4.432)$ & $(4.269)$ \\
\hline \multirow[t]{2}{*}{ Clothing } & 2.187 & 1.777 & 1.930 & 1.825 & 1.930 \\
\hline & (2.631) & (2.819) & $(2.814)$ & (2.858) & $(2.761)$ \\
\hline \multirow[t]{2}{*}{ Acquiring fee } & & -0.742 & -1.001 & -0.854 & -0.803 \\
\hline & & $(1.441)$ & $(1.448)$ & $(1.464)$ & $(1.447)$ \\
\hline \multirow[t]{2}{*}{ Loyalty program } & & $10.19^{\star * *}$ & $10.60^{\star \star *}$ & $10.28^{\star * *}$ & $10.69^{\star * *}$ \\
\hline & & $(3.384)$ & $(3.400)$ & $(3.410)$ & (3.380) \\
\hline
\end{tabular}

(0)

Baseline

Variables model
(1)

Human capital
(2)

Infrastructural block
(3)

Institutional block
(4)

All blocks

$\begin{array}{llllll}\text { Competitive threat } & & 0.520 & 0.926 & 0.646 & 0.737 \\ \text { Regional center } & & (1.673) & (1.688) & (1.698) & (1.679) \\ & 0.439 & -3.013 & -2.665 & -3.059 & -2.480 \\ \text { Ln (GRP per capita) } & (3.635) & (4.254) & (4.259) & (4.312) & (4.183) \\ & 10.30^{\star \star *} & 11.21^{\star \star *} & 11.28^{\star \star *} & 11.20^{\star \star \star} & 11.08^{\star \star \star}\end{array}$




$$
\text { (3.081) }
$$

(3.300)

(3.367)

(3.259)

Ln (Retail volume per capita)

$$
1.148
$$

$-4.740$

$-2.754$

$-2.940$

$-4.233$

(7.848)

(7.799)

(7.922)

(7.729)

10-100m RUB turnover

$$
1.679
$$

2.806

2.211

2.341

2.694

(2.840)

(3.191)

(3.179)

1-10m RUB turnover

$$
-0.141
$$

$-0.00891$

$-0.447$

(3.228)

$-0.215$

(2.139)

(2.342)

(2.341)

$-0.265$

(2.301)

$<1$ m RUB turnover

$-6.403$

$-6.736$

$-6.656$

(2.370)

$-6.390$

(4.718)

(4.792)

(4.792)

$-6.907$

(4.710)

Human capital block

$-9.860^{\star *}$

(4.851)

$-10.51^{\text {** }}$

(4.433)

(4.449)

Infrastructural block

$-4.199^{*}$

$-4.376^{*}$

(2.163)

Institutional block

$-0.0491$

$-2.123$

(3.439)

PCA of blocks

$-0.358$

(0.730)

Constant

$-44.59^{*}$

$-19.28$

$-30.49$

$-28.73$

$-21.38$

(26.65)

(29.27)

(28.97)

(29.34)

(28.77)

$\begin{array}{llllll}\text { Observations } & 738 & 715 & 715 & 715 & 715 \\ \text { df } & 25 & 29 & 29 & 29 & 31 \\ \text { N of observations } & 738 & 715 & 715 & 715 & 715\end{array}$

Standard errors in parentheses

${ }^{* * *} p<0.01,{ }^{* *} p<0.05,{ }^{*} p<0.1$

Source: Author's calculations 
Table 3. Perception of higher individual acceptance barriers and its effect on merchant's cashless revenue share 2014

\begin{tabular}{|c|c|c|c|c|c|c|c|c|}
\hline & (5) & (6) & (7) & (8) & (9) & (10) & (11) & (12) \\
\hline Variables & $\begin{array}{l}\text { Human } \\
\text { capital }\end{array}$ & Connection & Breakages & $\begin{array}{l}\text { Bank } \\
\text { support }\end{array}$ & $\begin{array}{l}\text { Acquiring } \\
\text { support }\end{array}$ & $\begin{array}{l}\text { Remittances } \\
\text { speed }\end{array}$ & $\begin{array}{l}\text { All } \\
\text { barriers }\end{array}$ & $\begin{array}{l}\text { PCA of } \\
\text { barriers }\end{array}$ \\
\hline Hypermarket & 6.301 & 6.158 & 6.409 & 6.918 & 6.691 & 6.346 & 6.267 & 6.348 \\
\hline & $(4.325)$ & (4.312) & (4.344) & $(4.385)$ & (4.391) & $(4.357)$ & $(4.164)$ & $(4.410)$ \\
\hline $\begin{array}{l}\text { Specialized } \\
\text { (food) }\end{array}$ & -3.550 & -2.816 & -2.300 & -2.672 & -2.667 & -2.785 & -3.463 & -2.694 \\
\hline & (5.118) & (5.091) & (5.134) & (5.144) & (5.152) & (5.135) & (4.954) & (5.161) \\
\hline $\begin{array}{l}\text { Specialized } \\
\text { (non-food) }\end{array}$ & 3.302 & 4.039 & 3.609 & 3.151 & 3.191 & 3.456 & 3.882 & 3.546 \\
\hline & (3.539) & (3.549) & (3.558) & (3.578) & (3.605) & (3.564) & (3.440) & (3.615) \\
\hline Kiosk, stall & -6.512 & -6.476 & -6.587 & -6.769 & -6.692 & -6.561 & -6.324 & -6.600 \\
\hline & (5.266) & (5.249) & (5.289) & (5.315) & $(5.321)$ & (5.302) & $(5.056)$ & (5.338) \\
\hline Pharmacy & -2.269 & -1.625 & -1.403 & -2.007 & -1.893 & -1.796 & -2.249 & -1.659 \\
\hline & (3.839) & $(3.817)$ & (3.856) & (3.874) & (3.884) & (3.855) & (3.699) & (3.894) \\
\hline $\begin{array}{l}\text { Retail trade } \\
\text { chain }\end{array}$ & 7.983 & 7.942 & 7.712 & 7.700 & 7.856 & 7.874 & 7.079 & 8.062 \\
\hline & (5.833) & $(5.813)$ & $(5.863)$ & $(5.886)$ & (5.899) & (5.873) & $(5.620)$ & (5.903) \\
\hline Central FR & $-8.948^{\star}$ & $-10.51^{\star *}$ & $-10.73^{* *}$ & $-11.10^{* *}$ & $-10.83^{* *}$ & $-10.55^{\star *}$ & $-8.987^{* *}$ & $-10.60^{* *}$ \\
\hline & $(4.736)$ & $(4.655)$ & (4.688) & $(4.730)$ & $(4.725)$ & $(4.703)$ & $(4.582)$ & $(4.740)$ \\
\hline Northwestern FR & -8.062 & -8.713 & -9.002 & -9.335 & -9.028 & -9.216 & -7.910 & -9.042 \\
\hline & $(6.516)$ & $(6.481)$ & (6.529) & (6.569) & $(6.568)$ & $(6.539)$ & (6.262) & $(6.586)$ \\
\hline North FR & -7.903 & -7.548 & -7.759 & -7.690 & -7.697 & -7.736 & -7.640 & -7.741 \\
\hline & (4.933) & $(4.918)$ & (4.954) & $(4.976)$ & $(4.983)$ & $(4.963)$ & $(4.734)$ & (4.995) \\
\hline Volga FR & -4.469 & -4.231 & -4.472 & -4.199 & -4.192 & -4.182 & -4.938 & -4.164 \\
\hline & (3.501) & $(3.485)$ & (3.520) & (3.531) & $(3.538)$ & $(3.520)$ & $(3.366)$ & (3.543) \\
\hline
\end{tabular}


North

Caucasian/South

FR

$\begin{array}{llllllll}-12.48^{* *} & -11.39^{*} & -11.66^{*} & -12.50^{* *} & -12.29^{*} & -11.76^{*} & -11.31^{*} & -11.95^{*} \\ (6.310) & (6.320) & (6.351) & (6.375) & (6.378) & (6.381) & (6.131) & (6.431)\end{array}$

Far Eastern FR

$\begin{array}{llllllll}-6.397 & -6.689 & -5.764 & -5.677 & -5.659 & -5.422 & -7.476 & -5.724 \\ (4.830) & (4.822) & (4.838) & (4.858) & (4.865) & (4.863) & (4.706) & (4.874)\end{array}$

Over $1 \mathrm{~m}$

population

2.004

$0.846 \quad 1.969$

(5)

(6)

(7)

(8)

(9)

(10)

(11)

(12)

Human

Bank

Acquiring Remittances All

capital Connection Breakages support

support speed

barriers

PCA of

Variables

Between 500k

and $1 \mathrm{~m}$

population

$\begin{array}{llll}5.999 & 5.573 \quad 5.547 \quad 5.767\end{array}$

5.773

5.718

5.032

5.870

(4.018) (4.012)

(4.044)

(4.053)

(4.066)

(4.051)

(3.892)

(4.068)

Less than $100 \mathrm{k}$

population

$\begin{array}{llllllll}-7.655^{\star \star} & -8.143^{\star *} & -7.747^{\star *} & -7.946^{\star \star} & -8.029^{\star *} & -7.776^{\star \star} & -7.541^{\star \star} & -7.923^{\star \star} \\ (3.811) & (3.800) & (3.830) & (3.839) & (3.847) & (3.840) & (3.703) & (3.854)\end{array}$

Market presence

(years)

$\begin{array}{llllllll}-0.100 & -0.0782 & -0.109 & -0.106 & -0.103 & -0.0975 & -0.0802 & -0.0996 \\ (0.165) & (0.166) & (0.166) & (0.167) & (0.167) & (0.166) & (0.161) & (0.167)\end{array}$

Food and

beverage

$-2.658 \quad-2.060$

$-2.600$

$-3.034 \quad-2.813 \quad-2.655$

$-2.426 \quad-2.522$

(3.041) (3.056)

(3.055)

(3.093)

(3.092) (3.061)

(2.964)

(3.109)

Durables

$6.876 \quad 7.042$

$7.416^{*}$

$7.397^{\star}$

7.178

7.018

6.864

7.176

(4.370) (4.348)

(4.387)

(4.415)

(4.415)

(4.401)

(4.194)

(4.429)

Clothing

$1.777 \quad 1.884$

2.119

1.887

1.875

1.683

$2.142 \quad 1.790$

(2.819) (2.808)

(2.839)

(2.845)

(2.852)

(2.843)

(2.718) (2.857)

Acquiring fee

$$
-0.742 \quad-1.074
$$

$-0.749$

$-0.967$

$-0.851$

$-1.062$

$-1.134-0.890$

(1.441) (1.449)

(1.446)

(1.450)

(1.450)

(1.470)

(1.454)

(1.453)

Loyalty program

$10.19^{* * *} \quad 10.58^{* * *}$ $10.53^{* * *} \quad 10.31^{* * *}$ $10.29^{* \star *}$ $10.12^{\star \star \star}$ $10.68^{* \star *} \quad 10.28^{\star \star *}$ 

(3.384)
(3.395)
(3.401)
(3.402)
(3.406)
(3.409)
(3.364)
(3.406)

Competitive

threat

$\begin{array}{llllllll}0.520 & 0.940 & 0.843 & 0.495 & 0.616 & 0.737 & 0.823 & 0.737 \\ (1.673) & (1.685) & (1.685) & (1.690) & (1.687) & (1.686) & (1.668) & (1.698)\end{array}$

Regional center

$\begin{array}{llllllll}-3.013 & -2.551 & -2.977 & -2.891 & -3.011 & -2.982 & -2.056 & -3.049 \\ (4.254) & (4.254) & (4.274) & (4.294) & (4.300) & (4.282) & (4.105) & (4.309)\end{array}$

Ln (GRP per capita)

$\begin{array}{llllllll}11.21^{* * *} & 11.19^{* * *} & 11.42^{* \star *} & 10.80^{* * *} & 11.09^{* * *} & 11.30^{* * *} & 10.77^{* * *} & 11.35^{* * *} \\ (3.305) & (3.294) & (3.323) & (3.361) & (3.354) & (3.328) & (3.214) & (3.363)\end{array}$

Ln (Retail volume per capita)

$\begin{array}{llllllll}-4.740 & -2.513 & -3.469 & -2.169 & -2.650 & -3.040 & -3.622 & -3.184 \\ (7.848) & (7.789) & (7.848) & (7.910) & (7.917) & (7.855) & (7.644) & (7.914)\end{array}$

10-100m RUB turnover

$\begin{array}{llllllll}2.806 & 2.263 & 2.297 & 2.460 & 2.366 & 2.296 & 2.882 & 2.289 \\ (3.191) & (3.171) & (3.198) & (3.215) & (3.217) & (3.204) & (3.057) & (3.229)\end{array}$

1-10m RUB

turnover

$\begin{array}{llllllll}0.00891 & -0.421 & -0.415 & -0.214 & -0.200 & -0.199 & -0.100 & -0.315\end{array}$

(2.342) (2.335)

(2.352) (2.360)

(2.368) (2.355)

(2.266) (2.371)

\section{(5)}

(6)

(7)

(8)

(9)

(10)

(11)

(12)

Human

Bank

Acquiring Remittances All

PCA of

Variables capital

Connection Breakages support support speed barriers barriers

$<1 \mathrm{~m}$ RUB

turnover

$\begin{array}{llllllll}-6.736 & -6.470 & -6.925 & -6.833 & -6.722 & -6.775 & -5.843 & -6.949 \\ (4.792) & (4.789) & (4.812) & (4.831) & (4.859) & (4.826) & (4.676) & (4.847)\end{array}$

Human capital

barrier

$-9.860^{\star *}$

$-10.91^{\text {** }}$

(4.433)

(4.438)

Connection

barrier

$-3.957^{\star}$

$-4.455^{\star}$

(2.255)

(2.506) 
Equipment breakages barrier

(4.668)
$-5.734$

$(4.730)$

$-5.862$

$-7.107$

(6.364)

Acquiring

support barrier

$-2.029$

$-2.508$

$(5.524)$

Remittances

speed barrier

$-3.455 \quad-2.066$

(4.153)

$(4.471)$

PCA of barriers

Constant

$\begin{array}{lll}-19.28 & -31.13 & -27.49\end{array}$

$-29.52$

$-29.23$

$-28.45$

$-21.40$

(28.33)

$-0.288$

(0.703)

(29.27) (28.93)

(29.11)

(29.22)

(29.28) (29.15)

(29.32)

\begin{tabular}{|c|c|c|c|c|c|c|c|c|}
\hline Observations & 715 & 715 & 715 & 715 & 715 & 715 & 715 & 715 \\
\hline df & 29 & 29 & 29 & 29 & 29 & 29 & 34 & 29 \\
\hline $\begin{array}{l}\mathrm{N} \text { of } \\
\text { observations }\end{array}$ & 715 & 715 & 715 & 715 & 715 & 715 & 715 & 715 \\
\hline $\begin{array}{l}\text { Standard errors } \\
\text { in parentheses }\end{array}$ & & & & & & & & \\
\hline $\begin{array}{l}{ }^{* *} p<0.01,{ }^{* *} \\
p<0.05,{ }^{*} p<0.1\end{array}$ & & & & & & & & \\
\hline
\end{tabular}

Source: Author's calculations 
Table 4. Educational and infrastructural proxies' effect on merchant's cashless revenue share, 2014

\begin{tabular}{|c|c|c|}
\hline Variables & $\begin{array}{l}\text { (13) } \\
\text { Number of university graduates per } \\
\text { capita }\end{array}$ & $\begin{array}{l}\text { (14) } \\
\text { Network services } \\
\text { volume }\end{array}$ \\
\hline Hypermarket & $\begin{array}{l}5.669 \\
(4.639)\end{array}$ & $\begin{array}{l}5.361 \\
(4.543)\end{array}$ \\
\hline Specialized (food) & $\begin{array}{l}-2.968 \\
(5.327)\end{array}$ & $\begin{array}{l}-2.629 \\
(5.249)\end{array}$ \\
\hline Specialized (non-food) & $\begin{array}{l}3.334 \\
(3.730)\end{array}$ & $\begin{array}{l}3.406 \\
(3.730)\end{array}$ \\
\hline Kiosk, stall & $\begin{array}{l}-7.849 \\
(5.401)\end{array}$ & $\begin{array}{l}-8.013 \\
(5.464)\end{array}$ \\
\hline Pharmacy & $\begin{array}{l}-1.700 \\
(4.062)\end{array}$ & $\begin{array}{l}-2.153 \\
(4.073)\end{array}$ \\
\hline Retail trade chain & $\begin{array}{l}9.043 \\
(5.989)\end{array}$ & $\begin{array}{l}9.053 \\
(6.045)\end{array}$ \\
\hline Central FR & $\begin{array}{l}-11.16^{\star \star} \\
(5.525)\end{array}$ & $\begin{array}{l}-7.507 \\
(4.836)\end{array}$ \\
\hline Northwestern FR & $\begin{array}{l}-9.664 \\
(7.193)\end{array}$ & $\begin{array}{l}-6.817 \\
(6.558)\end{array}$ \\
\hline North FR & $\begin{array}{l}-9.023^{*} \\
(5.085)\end{array}$ & $\begin{array}{l}-8.063 \\
(4.921)\end{array}$ \\
\hline Volga FR & $\begin{array}{l}-3.764 \\
(3.961)\end{array}$ & $\begin{array}{l}-3.412 \\
(3.653)\end{array}$ \\
\hline North Caucasian/South FR & $\begin{array}{l}-12.21^{*} \\
(6.597)\end{array}$ & $\begin{array}{l}-10.73^{*} \\
(6.431)\end{array}$ \\
\hline
\end{tabular}


Far Eastern FR

$-5.402$

(5.392)

2.195

(4.967)

5.845

(4.300)

$-7.980^{* *}$

(4.052)

$-0.0872$

(0.173)

$-2.858$

(3.165)

7.895*

(4.578)

2.132

(2.960)

$-1.298$

(1.457)
$-2.818$

2.034

(4.934)

5.429

(4.160)

$-9.331^{* *}$

(4.244)

$-0.0623$

(0.173)

$-3.224$

(3.237)

$7.786^{*}$

(4.563)

2.077

(2.954)

$-0.889$

(1.469)

(13)

Number of university graduates per

Network services

Variables

capita

volume

Loyalty program

$6.898^{* *}$

(3.264)

1.417

(1.701)

$-2.844$

Regional center
$6.948^{* *}$

(3.252)

1.425

(1.691)
$-2.465$ 


$$
\text { (4.546) }
$$

Ln (GRP per capita)

$10.95^{\star \star *}$

$12.80^{\star \star *}$

(3.545)

(3.600)

Ln (Retail volume per capita)

$-1.563$

3.696

(9.415)

10-100m RUB turnover

2.493

3.165

(3.310)

1-10m RUB turnover

$-0.223$

$-0.0227$

(2.445)

$<1$ m RUB turnover

$-7.643$

$-7.744$

(4.973)

Number of university graduates per capita

(4.753)

Network services volume

$0.602^{*}$

(0.340)

Constant

$-33.96$

$-69.27^{*}$

(34.06)

\section{Observations}

717

717

df

29

29

$\mathrm{N}$ of observations

717

717

Standard errors in parentheses

${ }^{* * *} p<0.01,{ }^{* *} p<0.05,{ }^{*} p<0.1$

Source: Author's calculations 
Table 5. Perception of higher acceptance barriers (in blocks) and its effect on merchant's cashless revenue share, 2017

\begin{tabular}{|c|c|c|c|c|c|}
\hline & $(0)$ & (1) & (2) & (3) & (4) \\
\hline Variables & $\begin{array}{l}\text { Baseline } \\
\text { model }\end{array}$ & $\begin{array}{l}\text { Human capital } \\
\text { block }\end{array}$ & $\begin{array}{l}\text { Infrastructural } \\
\text { block }\end{array}$ & $\begin{array}{l}\text { Institutional } \\
\text { block }\end{array}$ & All blocks \\
\hline Hypermarket & 2.861 & 4.329 & 4.475 & 4.084 & 3.972 \\
\hline & (3.590) & (3.703) & (3.643) & (3.678) & (3.673) \\
\hline Specialized (food) & $-6.837^{* * *}$ & $-8.948^{* * *}$ & $-8.869^{\star * *}$ & $-9.105^{\star \star \star}$ & $-9.059^{* * *}$ \\
\hline & (2.398) & $(2.566)$ & $(2.540)$ & $(2.556)$ & $(2.541)$ \\
\hline Specialized (non-food) & 11.09 & 4.923 & 4.799 & 4.278 & 3.988 \\
\hline & $(8.417)$ & (8.138) & (8.049) & $(8.110)$ & (8.067) \\
\hline Kiosk, stall & -1.428 & -6.126 & -5.742 & -5.431 & -5.037 \\
\hline & $(5.008)$ & $(5.177)$ & $(5.130)$ & $(5.164)$ & (5.138) \\
\hline Pharmacy & $-9.753^{\star \star *}$ & $-10.75^{\star \star \star}$ & $-10.76^{\star \star \star}$ & $-10.39^{* *}$ & $-10.72^{\star \star *}$ \\
\hline & (3.514) & $(4.117)$ & $(4.058)$ & $(4.085)$ & $(4.081)$ \\
\hline Retail trade chain & -0.232 & -1.121 & -1.090 & -1.646 & -1.652 \\
\hline & (2.827) & (3.027) & (2.992) & (3.027) & $(3.010)$ \\
\hline Food and beverage & -2.425 & -0.320 & -0.278 & 0.0198 & -0.0526 \\
\hline & $(2.460)$ & $(2.643)$ & (2.618) & $(2.633)$ & (2.619) \\
\hline Durables & 1.622 & 7.207 & 7.659 & 7.097 & 7.511 \\
\hline & $(4.854)$ & $(5.744)$ & $(5.687)$ & $(5.727)$ & (5.695) \\
\hline Clothing & 7.706 & 6.061 & 6.484 & 6.117 & 6.385 \\
\hline & $(7.706)$ & $(7.278)$ & $(7.203)$ & $(7.254)$ & $(7.213)$ \\
\hline 10-100m RUB turnover & -3.438 & -1.017 & -0.381 & -1.423 & -1.096 \\
\hline & (3.075) & (3.737) & (3.679) & $(3.714)$ & (3.717) \\
\hline 1-10m RUB turnover & -0.408 & 1.367 & 1.978 & 0.745 & 1.131 \\
\hline & (2.379) & (2.582) & (2.539) & $(2.580)$ & (2.592) \\
\hline$<1 \mathrm{~m}$ RUB turnover & 1.066 & 4.186 & 4.436 & 3.408 & 3.642 \\
\hline
\end{tabular}




\begin{tabular}{|c|c|c|c|c|c|}
\hline & $(2.857)$ & (3.043) & (3.013) & (3.056) & $(3.041)$ \\
\hline \multirow[t]{2}{*}{ Loyalty program } & & $5.228^{\star}$ & $5.372^{*}$ & $5.031^{*}$ & $5.151^{*}$ \\
\hline & & (2.825) & (2.803) & (2.810) & $(2.793)$ \\
\hline \multirow[t]{2}{*}{ Acquiring fee } & & -0.228 & -0.203 & -0.136 & -0.128 \\
\hline & & $(0.358)$ & $(0.355)$ & $(0.359)$ & $(0.357)$ \\
\hline \multirow[t]{2}{*}{ Competitive threat } & & $-4.646^{* *}$ & $-4.342^{* *}$ & $-4.704^{\star *}$ & $-4.341^{* *}$ \\
\hline & & $(1.892)$ & $(1.884)$ & $(1.875)$ & $(1.877)$ \\
\hline \multirow[t]{2}{*}{$\begin{array}{l}\text { Market presence } \\
\text { (years) }\end{array}$} & & $0.691^{* *}$ & $0.695^{\star *}$ & $0.725^{\star *}$ & $0.738^{\star *}$ \\
\hline & & $(0.340)$ & $(0.337)$ & $(0.338)$ & $(0.337)$ \\
\hline \multirow[t]{2}{*}{ Volga FR } & 0.822 & 2.305 & 1.665 & 3.818 & 2.743 \\
\hline & (4.512) & (5.089) & (5.042) & $(5.092)$ & $(5.114)$ \\
\hline \multirow[t]{2}{*}{ North FR } & 4.262 & $12.91^{* *}$ & $11.86^{\star}$ & $12.96^{\star *}$ & $11.34^{*}$ \\
\hline & (5.149) & (6.397) & (6.309) & $(6.294)$ & $(6.376)$ \\
\hline
\end{tabular}

North Caucasian/South FR

Far Eastern FR

$-2.895 \quad 0.636$

1.078

0.105

0.337

(4.353) (4.865)

(4.806)

(4.847)

(4.827)

Variables
(0)

Baseline

(1) model
Human capital block

\section{(2)}

Infrastructural block

\section{(3)}

(4)

\begin{tabular}{llllll}
\hline Central FR & & & & & \\
& $-10.66^{* * *}$ & $-9.424^{* *}$ & $-9.813^{* *}$ & $-10.32^{* *}$ & $-10.82^{* *}$ \\
Northwestern FR & $(3.913)$ & $(4.629)$ & $(4.576)$ & $(4.626)$ & $(4.616)$ \\
& -6.440 & -1.270 & -2.162 & -1.887 & -3.118 \\
& $(4.097)$ & $(5.119)$ & $(5.050)$ & $(5.067)$ & $(5.116)$
\end{tabular}


Over $1 \mathrm{~m}$ population
Between $500 \mathrm{k}$ and $1 \mathrm{~m}$
population

$\begin{array}{ll}6.556 & 1.951 \\ (4.662) & (5.294)\end{array}$

$-2.027 \quad-2.809$

(3.629)

$(4.085)$

2.390

(5.239)

0.703

(5.284)

1.533

$-12.44^{\star \star *}-12.30^{\star \star *}$

(2.778) (2.979)

$-7.474^{\star *} \quad-7.126^{\star}$

(4.104)

(3.642)

$5.540 *$

5.207

(3.623)

$-2.725$

(4.045)

$-3.637$

(4.085)

Less than 100k

population

(3.107)

8.128

$20.33^{*}$

(10.51)

$-11.32^{* * *}$

$-12.59^{\star \star \star}$

(2.953)

(3.004)

(2.986)

$-6.980^{\star}$

$-6.747^{*}$

$-6.941^{*}$

(4.063)

(4.088)

(4.066)

4.939

(3.540)

5.425

5.563

Ln (Retail volume per capita)

(8.902)

$-6.395$

(10.77)

$19.16^{\star}$

(10.37)

(3.571)

(3.590)

Human capital block

Infrastructural block

$-5.093^{\star *}$

(2.434)

$22.32^{\star \star}$

$20.05^{\star}$

(10.39)

(10.48)

$-2.689$

(10.80)

$-4.487^{\star}$

(2.445)

Institutional block

$-5.810^{\star \star}$

$-4.922^{*}$

(2.905)

(2.959)

PCA of blocks $\quad-2.447^{* *}$
$(0.959)$

Constant

$-264.0^{* *}$

$-246.4^{* *}$

$-289.1^{* * *}$

$-263.3^{\star *}$

(91.91) (106.9)

(106.1)

(106.4)

(107.1)

\begin{tabular}{|c|c|c|c|}
\hline Observations & 586 & 513 & 513 \\
\hline$d$ & 24 & 29 & 29 \\
\hline
\end{tabular}


$\begin{array}{llllll}\text { N of observations } & 586 & 513 & 513 & 513\end{array}$

Standard errors in parentheses

${ }^{* * *} p<0.01,{ }^{* *} p<0.05,{ }^{*} p<0.1$

Source: Author's calculations

Table 6. Perception of higher individual acceptance barriers and its effect on merchant's cashless revenue share, 2017

$\begin{array}{llllllll}(5) & (6) & (7) & (8) & (9) & (10) & \text { (11) }\end{array}$

\begin{tabular}{|c|c|c|c|c|c|c|c|c|}
\hline Variables & $\begin{array}{l}\text { Human } \\
\text { capital }\end{array}$ & Connection & Breakages & $\begin{array}{l}\text { Bank } \\
\text { support }\end{array}$ & $\begin{array}{l}\text { Acquiring } \\
\text { support }\end{array}$ & $\begin{array}{l}\text { Remittances } \\
\text { speed }\end{array}$ & $\begin{array}{l}\text { All } \\
\text { barriers }\end{array}$ & $\begin{array}{l}\text { PCA of } \\
\text { barriers }\end{array}$ \\
\hline Hypermarket & $\begin{array}{l}4.329 \\
(3.703)\end{array}$ & $\begin{array}{l}4.857 \\
(3.656)\end{array}$ & $\begin{array}{l}5.052 \\
(3.543)\end{array}$ & $\begin{array}{l}4.580 \\
(3.675)\end{array}$ & $\begin{array}{l}4.550 \\
(3.675)\end{array}$ & $\begin{array}{l}3.750 \\
(3.699)\end{array}$ & $\begin{array}{l}4.904 \\
(3.537)\end{array}$ & $\begin{array}{l}4.250 \\
(3.684)\end{array}$ \\
\hline $\begin{array}{l}\text { Specialized } \\
\text { (food) }\end{array}$ & $\begin{array}{l}-8.948^{\star \star *} \\
(2.566)\end{array}$ & $\begin{array}{l}-8.868^{\star \star \star} \\
(2.548)\end{array}$ & $\begin{array}{l}-8.785^{\star * *} \\
(2.474)\end{array}$ & $\begin{array}{l}-8.928^{\star \star \star} \\
(2.565)\end{array}$ & $\begin{array}{l}-8.913^{* \star *} \\
(2.562)\end{array}$ & $\begin{array}{l}-9.311^{* * *} \\
(2.565)\end{array}$ & $\begin{array}{l}-9.077^{\star \star *} \\
(2.440)\end{array}$ & $\begin{array}{l}-9.074^{\star \star *} \\
(2.562)\end{array}$ \\
\hline
\end{tabular}

Specialized

(non-food)

4.923

$5.619 \quad 5.967$

5.098

5.182

3.852

$5.558 \quad 4.561$

(8.138)

(8.075)

(7.833)

(8.126)

(8.117)

(8.136)

(7.741)

(8.125)

Kiosk, stall

$-6.126$

$-6.409$

$-5.360$

$-6.209$

$-6.082$

$-5.285$

$-4.887$

$-5.389$

(5.177)

(5.142)

(4.999)

(5.177)

(5.184)

(5.172)

(4.945)

(5.183)

Pharmacy

$-10.75^{\star \star \star} \quad-10.36^{\star \star}$

$-9.977^{* *}$

$-10.48^{* *}$

$-10.59^{\star * *}-10.95^{\star * *}$

$-9.856^{* *}-10.68^{* * *}$

(4.117)

(4.066)

(3.946)

(4.098)

(4.094)

(4.100)

(3.934)

(4.097)

Retail trade

chain

$\begin{array}{llllllll}-1.121 & -0.925 & -1.199 & -1.076 & -1.187 & -1.667 & -1.380 & -1.661 \\ (3.027) & (3.000) & (2.912) & (3.033) & (3.041) & (3.031) & (2.902) & (3.040)\end{array}$

Food and

beverage

$\begin{array}{llllllll}-0.320 & -0.292 & 0.307 & -0.261 & -0.240 & 0.255 & 0.779 & -0.0699 \\ (2.643) & (2.627) & (2.556) & (2.641) & (2.641) & (2.643) & (2.526) & (2.638)\end{array}$




$\begin{array}{lllllllll}\text { Durables } & 7.207 & 6.422 & 6.432 & 7.153 & 7.293 & 7.348 & 4.920 & 7.301 \\ & (5.744) & (5.725) & (5.526) & (5.741) & (5.736) & (5.743) & (5.491) & (5.742) \\ \text { Clothing } & 6.061 & 5.527 & 5.770 & 6.107 & 6.265 & 6.185 & 4.457 & 6.278 \\ & (7.278) & (7.231) & (7.000) & (7.267) & (7.270) & (7.274) & (6.912) & (7.274) \\ \begin{array}{l}10-100 m \text { RUB } \\ \text { turnover }\end{array} & -1.017 & -0.560 & 0.427 & -0.748 & -0.732 & -1.731 & 1.17 \mathrm{e}-05 & -0.911 \\ & (3.737) & (3.686) & (3.586) & (3.707) & (3.707) & (3.735) & (3.591) & (3.710) \\ \begin{array}{l}1-10 m \text { RUB } \\ \text { turnover }\end{array} & 1.367 & 1.666 & 2.667 & 1.566 & 1.611 & 0.514 & 1.914 & 1.377 \\ & (2.582) & (2.540) & (2.480) & (2.555) & (2.554) & (2.596) & (2.511) & (2.554)\end{array}$

$<1 \mathrm{~m}$ RUB

turnover

$\begin{array}{llllllll}4.186 & 4.179 & 5.058^{*} & 4.279 & 4.283 & 3.349 & 4.142 & 4.227\end{array}$

$\begin{array}{lllllll}(3.043) & (3.024) & (2.944) & (3.038) & (3.037) & (3.057) & (2.932)\end{array}$

$\begin{array}{llllllll}\text { Loyalty program } \quad 5.228^{*} & 5.044^{*} & 4.372 & 5.261^{*} & 5.352^{*} & 4.933^{*} & 3.417 & 5.270^{*}\end{array}$

$\begin{array}{llllll}(2.825) & (2.819) & (2.746) & (2.825)\end{array}$

(5)

(6) $\quad(7) \quad(8)$

(9)

(10)

$(11)$

(12)

\begin{tabular}{llllllllll} 
Variables & $\begin{array}{l}\text { Human } \\
\text { capital }\end{array}$ & Connection & Breakages & $\begin{array}{l}\text { Bank } \\
\text { support }\end{array}$ & $\begin{array}{l}\text { Acquiring } \\
\text { support }\end{array}$ & $\begin{array}{l}\text { Remittances } \\
\text { speed }\end{array}$ & $\begin{array}{l}\text { All } \\
\text { barriers }\end{array}$ & $\begin{array}{l}\text { PCA of } \\
\text { barriers }\end{array}$ \\
\hline Acquiring fee & -0.228 & -0.243 & -0.101 & -0.223 & -0.233 & -0.165 & -0.0372 & -0.188 \\
& $(0.358)$ & $(0.356)$ & $(0.347)$ & $(0.358)$ & $(0.358)$ & $(0.358)$ & $(0.344)$ & $(0.358)$
\end{tabular}

Competitive

threat

$\begin{array}{llllllll}-4.646^{* *} & -4.921^{* * *} & -4.807^{* * *} & -4.665^{* *} & -4.647^{* *} & -4.954^{* * *} & -5.466^{* * *} & -4.356^{* *} \\ (1.892) & (1.891) & (1.835) & (1.916) & (1.897) & (1.877) & (1.840) & (1.891)\end{array}$

Market presence

(years)

$0.691^{\star *}$

$0.684^{\star *}$

$0.696^{* *} \quad 0.680^{* *} \quad 0.671^{* *} \quad 0.746^{* *}$

$0.783^{* *} \quad 0.689^{* *}$

$(0.340)$

(0.338)

$(0.329)$

(0.340)

$(0.340) \quad(0.339)$

(0.326) (0.338)

Volga FR

$$
2.305
$$

$2.235 \quad 0.975$

2.443

2.457

5.280

2.825

2.171

(5.089)

(5.043)

(4.907)

(5.099)

(5.071)

(5.215)

(5.057)

(5.068)

North FR

$12.91^{* *} \quad 13.69^{* *}$

$10.50^{*}$

$13.32^{* *} \quad 13.09^{* *} \quad 14.43^{* *}$

$11.88^{*}$

$11.49^{*}$ 

(6.397)
(6.278)
(6.141)
(6.401)
(6.384)
(6.310)
(6.189)
(6.411)

North

Caucasian/South

FR

0.184

$-0.178$

$-0.627$

0.180

0.188

1.303

$\begin{array}{ll}-0.545 & -0.234\end{array}$

(5.857)

(5.826)

(5.651)

(5.892)

(5.854)

(5.856)

(5.647)

(5.851)

Far Eastern FR $\quad 0.636$

$0.265 \quad-0.296$

0.716

0.676

1.157

$-0.922$

0.0988

(4.865)

(4.838)

(4.686)

(4.896)

(4.861)

(4.843)

(4.697)

(4.864)

Central FR

$-9.424^{\star *}$

$-9.024^{* *}$

$-10.69^{\star \star}$

$-9.299^{\star *}$

$-9.357^{\star *}-9.353^{\star *}$

$-10.57^{\star *}-10.35^{\star *}$

(4.629) (4.579)

(4.461)

(4.661)

(4.625) (4.599)

(4.439)

(4.652)

Northwestern FR

$-1.270$

$-0.509$

$-2.604$

$-0.971$

$-1.015$

$-0.797$

$-2.071$

$-2.357$

(5.119) (5.026)

(4.894)

(5.138)

(5.075) (5.048)

(4.912)

(5.129)

Over $1 \mathrm{~m}$

population

$\begin{array}{llllllll}1.951 & 1.945 & 2.311 & 1.755 & 1.825 & 0.377 & 1.346 & 1.914 \\ (5.294) & (5.247) & (5.095) & (5.277) & (5.279) & (5.304) & (5.067) & (5.273)\end{array}$

Between 500k

and $1 \mathrm{~m}$ pop.

$\begin{array}{llllllll}-2.809 & -3.039 & -2.648 & -2.909 & -2.809 & -3.665 & -3.775 & -2.883 \\ (4.085) & (4.057) & (3.937) & (4.083) & (4.081) & (4.091) & (3.901) & (4.077)\end{array}$

Less than $100 \mathrm{k}$

population

$-12.30^{\star \star \star} \quad-12.76^{\star \star \star}$

$-10.92^{\star \star *}$

$-12.44^{\star * *}$

$-12.36^{\star \star \star}-13.05^{\star \star \star}$

$-11.91^{\star * \star}-11.82^{\star \star *}$

(2.979) (2.950)

(2.881)

(2.968)

(2.973)

(2.969)

(2.869)

(2.983)

Regional center

$-7.126^{*} \quad-7.280^{*}$

$-6.980^{*}$

$-7.165^{\star}$

$-7.218^{\star} \quad-7.202^{*}$

$-7.017^{*} \quad-6.971^{*}$

(4.104)

(3.952)

(4.102)

(4.096)

(4.095)

(3.894)

(4.099)

(5)

(6)

(7)

(8)

Bank

Human

Variables

capital

Connection

support
(9)

Acquiring Remittances support speed
(11)

(12)

\section{Ln (GRP per}

capita)

5.207

4.536

4.905

4.960

5.157

4.765

(3.638)

(3.565)

$20.46^{*}$

$20.33^{*}$
(3.558)

(3.447)

(3.621)

$20.88^{\star *}$
$17.97^{*}$ $20.89^{\star \star}$ $24.72^{\star *}$

All barriers

Ln (Retail

PCA of barriers volume per 
capita)
(10.51)
(10.36)
(10.09)
(10.50)
(10.52) (10.52)
(10.26) (10.47)

Human capital

barrier

0.185

(10.77)

Connection

barrier

$-3.220$

$-5.442^{\star *}$

(2.519)

Equipment

breakages

barrier

$-13.04^{\star \star \star}$

$-14.76^{\star \star \star}$

(3.167)

(3.409)

Bank support

barrier

$-0.890$

$-0.752$

(4.951)

Acquiring

support barrier

$-2.809$

5.314

(6.399)

Remittances

speed barrier

$-7.297^{\star \star}$

$-6.667^{\star *}$

(3.377)

(3.331)

PCA of barriers

$-1.295^{*}$

(0.748)

$\begin{array}{lllllllll}\text { Constant } & -264.0^{* *} & -262.8^{* *} & -231.8^{* *} & -267.9^{* *} & -265.1^{* *} & -310.0^{* * *} & -259.4^{* *} & -256.8^{* *} \\ & (106.9) & (106.0) & (103.2) & (106.8) & (106.9) & (107.7) & (104.4) & (106.5) \\ \text { Observations } & 513 & 513 & 513 & 513 & 513 & 513 & 513 & 513 \\ \text { df } & 29 & 29 & 29 & 29 & 29 & 29 & 34 & 29 \\ \begin{array}{l}\text { N of } \\ \text { observations }\end{array} & 513 & 513 & 513 & 513 & 513 & 513 & 513 & 513\end{array}$

Standard errors in parentheses. ${ }^{\star \star *} p<0.01,{ }^{\star \star} p<0.05,{ }^{\star} p<0.1$.

Source:

Author's calculations 
Table 7. Educational and infrastructural proxies' effect on merchant's cashless revenue share, 2017

\begin{tabular}{|c|c|c|}
\hline & (13) & (14) \\
\hline Variables & $\begin{array}{l}\text { Number of university graduates per } \\
\text { capita }\end{array}$ & $\begin{array}{l}\text { Network services } \\
\text { expenditures }\end{array}$ \\
\hline \multirow[t]{2}{*}{ Hypermarket } & 4.550 & 5.307 \\
\hline & (3.848) & (3.748) \\
\hline \multirow[t]{2}{*}{ Specialized (food) } & $-8.694^{* * *}$ & $-8.793^{* * *}$ \\
\hline & $(2.656)$ & $(2.608)$ \\
\hline \multirow[t]{2}{*}{ Specialized (non-food) } & 9.337 & 6.987 \\
\hline & $(8.411)$ & (8.290) \\
\hline \multirow[t]{2}{*}{ Kiosk, stall } & -3.524 & -5.515 \\
\hline & $(5.161)$ & $(5.137)$ \\
\hline \multirow[t]{2}{*}{ Pharmacy } & $-11.88^{\star \star \star}$ & $-10.64^{\star \star}$ \\
\hline & $(4.269)$ & $(4.193)$ \\
\hline \multirow[t]{2}{*}{ Retail trade chain } & -1.853 & -1.136 \\
\hline & (3.096) & (3.049) \\
\hline \multirow[t]{2}{*}{ Food and beverage } & -0.797 & -0.266 \\
\hline & $(2.738)$ & (2.699) \\
\hline \multirow[t]{2}{*}{ Durables } & 6.412 & 5.966 \\
\hline & $(5.992)$ & $(5.843)$ \\
\hline \multirow[t]{2}{*}{ Clothing } & 2.614 & 4.806 \\
\hline & $(7.488)$ & $(7.372)$ \\
\hline \multirow[t]{2}{*}{ 10-100m RUB turnover } & 0.359 & -0.327 \\
\hline & $(3.877)$ & $(3.741)$ \\
\hline \multirow[t]{2}{*}{ 1-10m RUB turnover } & 2.826 & 2.276 \\
\hline & $(2.667)$ & (2.584) \\
\hline
\end{tabular}




\begin{tabular}{|c|c|c|}
\hline$<1 \mathrm{~m}$ RUB turnover & 4.025 & 4.152 \\
\hline & (3.182) & $(3.110)$ \\
\hline Loyalty program & 4.701 & $4.950^{*}$ \\
\hline & $(2.898)$ & (2.859) \\
\hline Acquiring fee & -0.0719 & -0.149 \\
\hline & $(0.370)$ & $(0.363)$ \\
\hline Competitive threat & $-4.046^{\star *}$ & $-4.166^{\star \star}$ \\
\hline & $(1.932)$ & $(1.912)$ \\
\hline Market presence (years) & $0.636^{*}$ & $0.629^{*}$ \\
\hline & $(0.349)$ & $(0.345)$ \\
\hline Volga FR & $-7.401^{*}$ & -2.998 \\
\hline & $(4.001)$ & $(4.162)$ \\
\hline North FR & -4.102 & 0.327 \\
\hline & $(4.406)$ & $(4.581)$ \\
\hline North Caucasian/South FR & $-9.170^{\star *}$ & -6.563 \\
\hline & $(4.346)$ & $(4.199)$ \\
\hline Far Eastern FR & $-7.321^{*}$ & -5.733 \\
\hline & $(4.299)$ & $(3.946)$ \\
\hline Central FR & $-15.95^{\star \star \star}$ & $-13.38^{\star \star \star}$ \\
\hline & $(4.284)$ & $(3.810)$ \\
\hline & (13) & (14) \\
\hline Variables & $\begin{array}{l}\text { Number of university graduates per } \\
\text { capita }\end{array}$ & $\begin{array}{l}\text { Network services } \\
\text { expenditures }\end{array}$ \\
\hline Northwestern FR & $-10.06^{* *}$ & -6.434 \\
\hline & $(4.493)$ & $(4.610)$ \\
\hline Over $1 \mathrm{~m}$ population & $9.979^{* *}$ & 5.346 \\
\hline
\end{tabular}




$$
\text { (4.919) }
$$

Between $500 \mathrm{k}$ and $1 \mathrm{~m}$ population

$$
0.232
$$$$
-1.012
$$

Less than $100 \mathrm{k}$ population

Regional center

Number of university graduates per capita

Network services expenditures

Constant

Observations

df

$\mathrm{N}$ of observations
513

27

513
513

27

513

Standard errors in parentheses

${ }^{* * *} p<0.01,{ }^{* *} p<0.05,{ }^{*} p<0.1$

Source: Author's calculations 